Published in final edited form as:

Biochemistry. 2015 December 15; 54(49): 7178-7192. doi:10.1021/acs.biochem.5b01074.

\title{
Design, Synthesis, and Investigation of Novel Nitric Oxide (NO)- Releasing Prodrugs as Drug Candidates for the Treatment of Ischemic Disorders: Insights into NO-releasing prodrugs biotransformation and hemoglobin-NO biochemistry
}

\author{
Guoyan G. Xu§, Tanvi M. Deshpande ${ }^{\S, \pm}$, Mohini S. Ghatge ${ }^{\S, \pm}$, Akul Y. Mehta§ ${ }^{\S} \pm$, Abdel Sattar \\ M. Omar ${ }^{\|, \ddagger}$, Mostafa H. Ahmed ${ }^{\S, \pm}$, Jurgen Venitz ${ }^{\dagger}$, Osheiza Abdulmalik ${ }^{\Uparrow}$, Yan Zhang ${ }^{\S}$, and \\ Martin K. Safo $\$, \pm,{ }^{*}$ \\ $\S$ Department of Medicinal Chemistry, School of Pharmacy, Virginia Commonwealth University, \\ Richmond, VA 23298 \\ †Department of Pharmaceutics, School of Pharmacy, Virginia Commonwealth University, \\ Richmond, VA 23298 \\ \pm The Institute for Structural Biology, Drug Discovery, and Development, School of Pharmacy, \\ Virginia Commonwealth University, Richmond, VA 23298 \\ "Department of Pharmaceutical Chemistry, Faculty of Pharmacy, King Abdulaziz University, \\ Alsulaymanyah, Jeddah 21589, Saudi Arabia \\ ¥Department of Pharmaceutical Chemistry, Faculty of Pharmacy, Al-Azhar University, Cairo \\ 11884, Egypt \\ IDivision of Hematology, The Children's Hospital of Philadelphia, PA 19104
}

\section{Abstract}

We have developed novel NO-releasing prodrugs of efaproxiral (RSR13) for their potential therapeutic applications in a variety of diseases with underlying ischemia. RSR13 is an allosteric effector of hemoglobin $(\mathrm{Hb})$ that decreases the protein's affinity for oxygen, thereby increasing tissue oxygenation. NO in the form of ester prodrugs has been found useful in managing several cardiovascular diseases by increasing blood flow and oxygenation in ischemic tissues, due to its vasodilatory property. We synthesized three NO-donor ester derivatives of RSR13 (DD-1, DD-2 and DD-3) by attaching the NO-releasing moieties, nitrooxyethyl, nitrooxypropyl, and 1(pyrrolidin-1-yl)diazen-1-ium-1,2-diolate, respectively, to the carboxylate of RSR13. In-vitro studies demonstrated that the compounds released NO in a time-dependent manner when incubated with L-cysteine $(1.8-9.3 \%)$ or human serum $(2.3-52.5 \%)$; and also reduced $\mathrm{Hb}$ affinity for oxygen in whole blood $\left(\Delta \mathrm{P}_{50}\right.$ of $4.9-21.7 \mathrm{mmHg}$ vs $25.4-32.1 \mathrm{mmHg}$ for RSR13).

\footnotetext{
*Corresponding author: Martin K. Safo, 800 E. Leigh Street, Suite 212, Richmond, VA 23219, Phone: (804) 828-7291; msafo@vcu.edu.

Present address of Tanvi M. Deshpande: Department of Pharmaceutical Sciences University of Maryland School of Pharmacy 20 N Pine St, Room S650 Baltimore, MD 21201

The authors, Guoyan G. Xu, Tanvi M. Deshpande, and Mohini S. Ghatge contributed equally to this work.

The coordinate has been deposited at the PDB with accession code of 5E29.
} 
Crystallographic studies showed RSR13, the hydrolysis product of the reaction between DD-1 and deoxygenated $\mathrm{Hb}$, bound to the central water cavity of $\mathrm{Hb}$. Also, the hydrolysis product, $\mathrm{NO}$ was observed exclusively bound to the two a-hemes; the first such HbNO structure to be reported, capturing the previously proposed physiological bis-ligated nitrosylHb species. Finally, nitrate was observed bound to $\beta$ His 97 . UPLC-MS analysis of the compounds incubated with matrices used for the various studies demonstrated the presence of the predicted reaction products. Our findings, beyond the potential therapeutic application, provide valuable insights into the biotransformation of NO-releasing prodrugs and their mechanism of action, as well as hemoglobin-NO biochemistry at the molecular level.

\section{Graphical abstract}

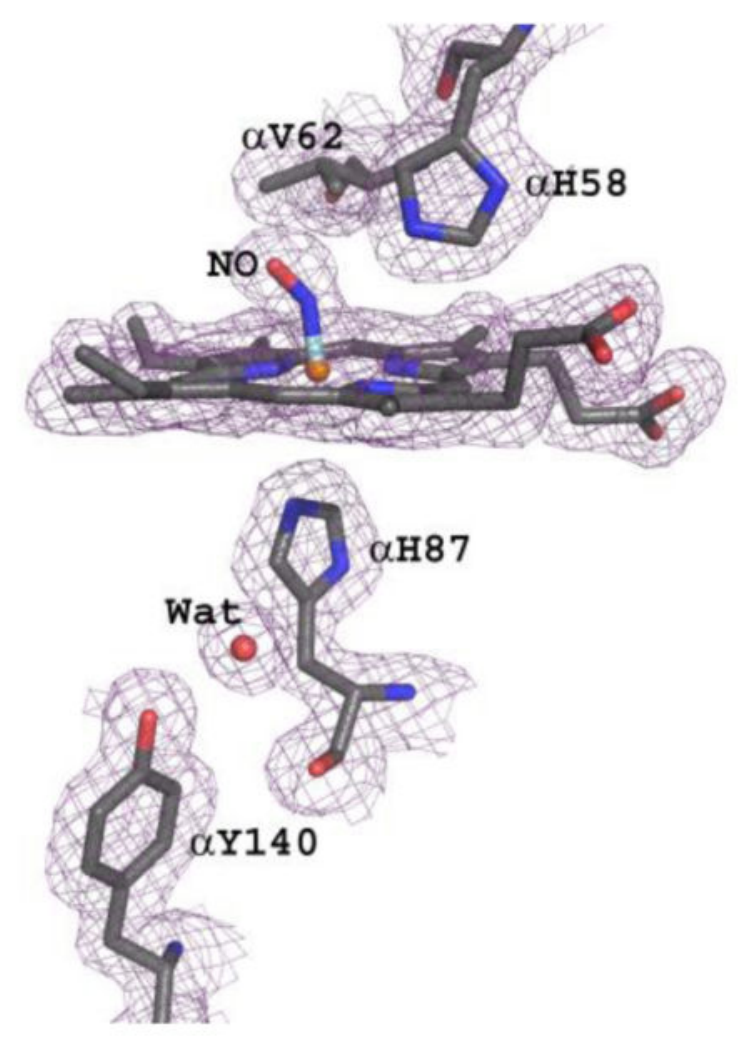

Hypoxemia, defined as insufficient oxygen $\left(\mathrm{O}_{2}\right)$ concentration/partial pressure of oxygen $\left(\mathrm{pO}_{2}\right)$ in arterial blood, is a condition that underlies a myriad of pulmonary, vascular and blood-related pathologies, including anemia, acute respiratory distress syndrome (ARDS), cardiovascular diseases, congenital heart disease, chronic obstructive pulmonary disease (COPD), emphysema, pneumonia, pneumothorax, pulmonary edema, pulmonary embolism, pulmonary fibrosis, and sleep apnea. Consequently, hypoxemia can often lead to tissue hypoxia or ischemia in essential organs, compromising their physiological functioning. These conditions can be reversed by increasing or improving oxygen delivery to these tissues by various interventions, e.g., by increasing $\mathrm{O}_{2}$-loading in the lung, enhancing organ perfusion and/or increasing $\mathrm{O}_{2}$ unloading in the tissue capillaries, an approach that has 
proven beneficial particularly in attenuating ischemic death resulting from ischemic heart attacks $^{1}$.

Hemoglobin $(\mathrm{Hb})$, the primary molecule responsible for maintaining adequate $\mathrm{O}_{2}$ levels in the blood and tissues, functions between two allosteric states: the tense or T-state (unliganded or deoxygenated $\mathrm{Hb}$ ), which possesses low $\mathrm{O}_{2}$-affinity, and the relaxed or Rstate (liganded or oxygenated $\mathrm{Hb}$ ), which exhibits high $\mathrm{O}_{2}$-affinity. The equilibrium between the R- and T-states, which is closely tied to $\mathrm{O}_{2}$ binding and its release, can be modulated by synthetic allosteric modifiers of $\mathrm{Hb}^{2}$. For instance, effectors that shift the oxygen equilibrium curve (OEC) to the left produce $\mathrm{R}$-state/high $\mathrm{O}_{2}$-affinity $\mathrm{Hb}$ that more readily binds and holds $\mathrm{O}_{2}$, while shifting the OEC to the right produces T-state/low $\mathrm{O}_{2}$-affinity $\mathrm{Hb}$ that readily releases $\mathrm{O}_{2}$. The degree of shift in the OEC is reported as a decrease (left-shift) or increase (right-shift) in $\mathrm{P}_{50}$ (oxygen tension, $\mathrm{pO}_{2}$, at $50 \% \mathrm{Hb} \mathrm{O}_{2}$ saturation). Approximately, $25 \%$ of the oxygen bound to $\mathrm{Hb}$ is released in the tissue capillaries at physiological $\mathrm{pO}_{2}$ of $\sim 20 \mathrm{mmHg}$ during each circulation cycle. The discovery that endogenous 2,3-DPG (2,3-diphosphoglycerate) decreases the $\mathrm{O}_{2}$-affinity of $\mathrm{Hb}$ to allow efficient release of $\mathrm{O}_{2}$ to tissues prompted the search for synthetic $\mathrm{Hb}$ effectors that act similarly to 2,3-DPG but are more potent, i.e. could release more $\mathrm{O}_{2}$ to tissue. $\mathrm{L} 35$ (3,5trichlorophenylureido-phenoxy-methylpropionic acid), a bezafibrate derivative, was one of the earliest synthetic effector found to decrease $\mathrm{Hb}$ affinity for $\mathrm{O}_{2}$, which in turn stimulates the release of $\mathrm{O}_{2}$ to tissue ${ }^{3}$. A recent study by Liong and co-workers demonstrated that paramagnetic nanoparticles (PMNPs) coated with L35 (L35-PMNPs) were able to increase targeted tissue $\mathrm{pO}_{2}$ (using magnetic fields) without inducing any systemic or microhemodynamic changes in hamsters ${ }^{4}$. Efaproxiral or RSR13, (2-[4[[(3,5dimethylanilino)carbon]methyl]phenoxyl]-2-methylpropionic acid; Fig. 1) is another synthetic allosteric effector that binds to the central water cavity of $\mathrm{Hb}$ and decreases the protein's affinity for $\mathrm{O}_{2}$, allowing enhancement of $\mathrm{O}_{2}$ release and delivery to ischemic and hypoxic tissues ${ }^{2,5}$. This property has led to this compound being extensively studied or proposed for treating disease states that decrease blood flow to tissues, such as vessel narrowing or weakening of heart pumping capacity, stroke, shock, myocardial ischemia, cerebral traumas, and angina, as well as a radiation enhancer in the radiotherapy of hypoxic tumors $^{6-8}$.

Another molecule that plays a crucial role in regulating $\mathrm{O}_{2}$-delivery to tissues is nitric oxide (NO). In fact, $\mathrm{NO}$ is essential in many aspects of human physiology, particularly in cardiovascular homeostasis due to its potent vasodilatory effects ${ }^{9-11}$. It also inhibits vascular remodeling, affecting the multi-step cascade of events involved in leukocyte, platelet and endothelial activation ${ }^{12}$. NO also increases erythrocyte mobility and oxygen delivery in ischemic tissue ${ }^{13}$, and acts as a critical mediator of mucosal defense and repair ${ }^{14}$. NO is produced from $\mathrm{L}$-arginine in the vascular endothelium by nitric oxide synthases ${ }^{15}$, from nitrite/nitrate in the erythrocyte by $\mathrm{Hb}^{16}$ or in the stomach or tongue by sequential reduction of nitrate ${ }^{17-20}$. Due to its critical physiological roles, the NO deficiency is implicated in numerous pathological conditions. In particular, reduced local bioavailability of NO in the endothelium is closely associated with coronary artery disease and its risk factors, including diabetes, hypertension, and obesity. Inhaled NO has been shown to reduce the severity and duration of vaso-occlusive crisis in sickle cell patients ${ }^{21,22}$, and to provide therapeutic 
benefits in acute respiratory distress syndrome ${ }^{23-25}$. In addition, long-lived circulating NOreleasing nanoparticles (NO-nps) have been shown to decrease blood pressure, induce vasodilation and prevent cardiovascular collapse during hemorrhagic in animal models ${ }^{26,27}$. Compounds with NO-releasing abilities, e.g., nitroglycerine, amyl nitrite, isosorbide dinitrate, NO-NSAIDS, nitrosothiols, nicorandil, sinitrodil, have been studied and/or used for the management of various ischemic syndromes, e.g., cardiovascular disease, pulmonary hypertension, acute lung distress syndrome, etc ${ }^{28-36}$.

Red blood cells (RBC) and $\mathrm{Hb}$ are intimately involved in NO homeostasis, although not without controversies. Studies suggest deoxygenated $\mathrm{Hb}$ (deoxyHb) to account for almost all NO production in RBC under tissue hypoxia or ischemia or low-blood flow conditions, converting nitrite at the heme moiety to NO and forming methemoglobin (metHb) ${ }^{16,37-40}$. Consistently, nitrite has been shown to be vasoactive under physiological conditions ${ }^{37,41-44}$. $\mathrm{NO}$ is also capable of reacting directly with the heme of deoxyHb or oxyHb to form nitrosylHb (HbNO), or with the heme of oxyHb to form metHb and nitrate - with the latter reaction suggested to be a major pathway for removal of excess NO from the body ${ }^{45-47}$.

The crystal structure of deoxyHb in complex with $\mathrm{NO}$ coordinated to all four hemes (tetraligated $\mathrm{T}$-state $\mathrm{HbNO}$; obtained by exposing deoxyHb crystals to $\mathrm{NO}$ gas) has been reported $^{48}$. Richter-Addo and co-workers also recently reported the crystal structure of Rstate $\mathrm{oxyHb}$ with $\mathrm{NO}$ bound to all four heme molecules (tetra-ligated R-state $\mathrm{HbNO}{ }^{49}$. In addition to interacting with the hemes of both deoxyHb and oxyHb to form $\mathrm{HbNO}$ derivatives, $\mathrm{NO}$ also forms a covalent $\mathrm{Hb}$ adduct with $\beta \mathrm{Cys} 93$ of oxyHb to form $\mathrm{S}$-nitrosoHb $(\mathrm{HbSNO})^{50-52}$ that has been proposed as a reservoir for NO. The crystal structure of $\mathrm{HbSNO}$ has been reported by the Arnone's group, which was later revised to be actually $\mathrm{HbSNOH}^{48,53}$.

In view of the potential beneficial effect of increasing local NO bioavailability and tissue oxygenation, we have combined the pharmacological effects of RSR13 and NO by derivatizing RSR13 with the following NO-releasing groups, nitrooxyethyl, nitrooxypropyl, and 1-(pyrrolidin-1-yl)diazen-1-ium-1,2-diolate to form DD-1, DD-2 and DD-3 (Fig. 1), respectively. These three compounds were further evaluated in-vitro for their NO-releasing ability, their effects on $\mathrm{Hb}-\mathrm{O}_{2}$ binding, their reaction products in the presence of various biological and non-biological matrices, as well as atomic interaction with $\mathrm{Hb}$.

\section{Experimental Procedures}

\section{Materials and General Procedure}

All reagents used in the syntheses, functional assays and other studies were purchased from Sigma-Aldrich corporation or the Fisher scientific company and used without purification. Routine thin-layer chromatography (TLC) was performed on silica gel GHIF plates (250 $\mu \mathrm{m}, 2.5 \times 10 \mathrm{~cm}$; Analtech Inc., Newark, DE). Column chromatography was performed on silica gel (grade 60 mesh; Bodman Industries, Aston, PA). Melting points were determined on a Fisher-Scientific melting point apparatus and were uncorrected. ${ }^{1} \mathrm{H}-\mathrm{NMR}$ and ${ }^{13} \mathrm{C}$ NMR spectra were obtained on a Bruker $400 \mathrm{MHz}$ spectrometer and tetramethylsilane (TMS) was used as an internal standard. Peak positions are given in parts per million $(\delta)$. 
High resolution mass spectrometry (HRMS) was recorded on a Perkin Elmer Flexar UHPLC with AxION 2 Time of Flight (TOF) Mass Spectrometer and the molecular weight of the compounds was within $0.05 \%$ of calculated values. Infrared spectra were obtained on a Thermo Nicolet iS10 FT-IR. Purity of the compounds was determined by HPLC using a Varian Microsorb 100-5 C18 column $(250 \times 4.6 \mathrm{~mm})$, acetonitrile $(0.1 \%$ TFA $) / W a t e r$ mobile phase and using Prostar $325 \mathrm{UV}$-Vis $(254 \mathrm{~nm})$ as the detector.

Human blood samples for functional/biological assays were obtained from healthy volunteers at Virginia Commonwealth University (VCU). The use of the biological samples has been reviewed and approved by the IRB, in accordance of institutional regulations. Hemoglobin for functional and/or crystallographic studies was purified from discarded blood or $\mathrm{RBCs}^{54}$ left over from red cell exchange from the VCU Hospital or the Children's Hospital of Philadelphia or from the American Red Cross.

\section{Synthesis of 2-(nitrooxy)ethyl-2-(4-(2-(3,5-dimethylphenyl)amino)-2-oxoethyl)phenoxy)-2- methylpropanoate, DD-1 $(n=1)$}

To stirred concentrated sulfuric acid (98\%, $3 \mathrm{mmol})$ concentrated nitric acid (70\%, $3 \mathrm{mmol})$ was added dropwise at $0{ }^{\circ} \mathrm{C}$ under nitrogen. The mixture was stirred for $10 \mathrm{~min}$ at the same temperature followed by addition of 2-bromoethanol $(0.31 \mathrm{~g}, 2.5 \mathrm{mmol})$ in anhydrous dichloromethane $(0.5 \mathrm{~mL})$ dropwise while keeping the internal temperature below $5{ }^{\circ} \mathrm{C}$. After $3 \mathrm{~h}$ the reaction was quenched with water $(2 \mathrm{~mL})$. Dichloromethane $(10 \mathrm{~mL})$ was added and the organic phase was separated, washed with water $(3 \mathrm{~mL})$, dried over $\mathrm{Na}_{2} \mathrm{SO}_{4}$, and concentrated to give bromoethyl nitrate, which was used without further purification.

$\operatorname{RSR} 13(0.58 \mathrm{~g}, 1.7 \mathrm{mmol})$ and potassium carbonate $(0.55 \mathrm{~g}, 4.0 \mathrm{mmol})$ were added to a solution of bromoethyl nitrate in anhydrous DMF $(4 \mathrm{~mL})$. The reaction mixture was allowed to stir for $24 \mathrm{~h}$ at room temperature, then was diluted with EtOAc $(15 \mathrm{~mL})$, washed with water $(3 \times 4 \mathrm{~mL})$, dried over $\mathrm{Na}_{2} \mathrm{SO}_{4}$, and evaporated under reduced pressure to give a crude product, which was purified by silica gel column chromatography eluting with hexanes/ EtOAc (2:1) to yield $0.7 \mathrm{~g}$ of the titled compound as a white-colored solid with yield of 95.8\%. HPLC purity: $96.5 \%$ (Retention time: $4.85 \mathrm{~min} .30 \% \mathrm{H}_{2} \mathrm{O}$ and $70 \% \mathrm{MeCN}$ over 30 min at $254 \mathrm{~nm}$ on Varian C18 column) M.P.; $98-99{ }^{\circ} \mathrm{C}$. IR (neat, $\mathrm{cm}^{-1}$ ) $\nu_{\max }: 3294.96$, 1741.66, 1637.10, 1507.73, 1272.82, 1141.33. $\left.{ }^{1} \mathrm{H} \mathrm{NMR} \mathrm{(400} \mathrm{MHz,} \mathrm{CDCl}_{3}\right): \delta 7.20$ (d, $J=$ $8.99 \mathrm{~Hz}, 2 \mathrm{H}), 7.04$ (br s, 3H), 6.85 (d, $J=8.35 \mathrm{~Hz}, 2 \mathrm{H}), 6.72(\mathrm{~s}, 1 \mathrm{H}), 4.63(\mathrm{~m}, 2 \mathrm{H}), 4.46(\mathrm{~m}$, 2H), 3.64 (s, 2H), 2.25 (s, 6H), 1.62 (s, 6H). $\left.{ }^{13} \mathrm{C} \mathrm{NMR} \mathrm{(100} \mathrm{MHz,} \mathrm{CDCl}_{3}\right): \delta$ 174.00, 169.23, 154.86, 138.79, 137.63, 130.54, 128.53, 126.30, 119.81, 117.70, 79.33, 70.19, 61.10, 44.16, 25.52, 21.42. HRMS calc. $\mathrm{m} / \mathrm{z}$ for $\left[\mathrm{C}_{22} \mathrm{H}_{26} \mathrm{~N}_{2} \mathrm{O}_{7} \mathrm{Na}\right]^{+}: 453.1637$, found: 453.1710 .

\section{Synthesis of 2-(nitrooxy)propyl 2-(4-(2-(3,5-dimethylphenyl)amino)-2-oxoethyl)phenoxy)-2- methylpropanoate, DD-2 ( $n=2)$}

To a stirring solution of concentrated sulfuric acid $(98 \%, 3 \mathrm{mmol})$ was slowly added concentrated nitric acid $(70 \%, 3 \mathrm{mmol})$ dropwise at $0{ }^{\circ} \mathrm{C}$ under nitrogen gas protection. The mixture was stirred for $10 \mathrm{~min}$ at the same temperature followed by addition of 3bromopropanol $(0.35 \mathrm{~g}, 2.5 \mathrm{mmol})$ in anhydrous dichloromethane $(0.5 \mathrm{~mL})$ dropwise while 
keeping the internal temperature below $5{ }^{\circ} \mathrm{C}$. After stirring for $3 \mathrm{~h}$ the reaction was quenched with water $(2 \mathrm{~mL})$. Dichloromethane $(10 \mathrm{~mL})$ was added and the organic phase was separated, washed with water $(3 \mathrm{~mL})$, dried over $\mathrm{Na}_{2} \mathrm{SO}_{4}$, and concentrated to give bromopropyl nitrate, which was used without further purification.

RSR13 $(0.58 \mathrm{~g}, 1.7 \mathrm{mmol})$ and potassium carbonate $(0.55 \mathrm{~g}, 4.0 \mathrm{mmol})$ were added to a solution of bromopropyl nitrate in anhydrous DMF $(4 \mathrm{~mL})$. The reaction mixture was allowed to stir for $24 \mathrm{~h}$ at room temperature, diluted with EtOAc $(15 \mathrm{~mL})$, washed with water $(3 \times 4 \mathrm{~mL})$, dried over $\mathrm{Na}_{2} \mathrm{SO}_{4}$, and evaporated under reduced pressure to give a crude product, which was purified by silica gel column chromatography eluting with hexanes/ EtOAc (2:1) to yield $0.7 \mathrm{~g}$ of titled compound as a colorless oil with yield of 92.6\%. HPLC purity: $97.4 \%$. (Retention time: $5.34 \mathrm{~min} .30 \% \mathrm{H}_{2} \mathrm{O}$ and $70 \% \mathrm{MeCN}$ over $30 \mathrm{~min}$ at $254 \mathrm{~nm}$ on Varian C18 column) IR (neat, $\mathrm{cm}^{-1}$ ) $v_{\max }: 3292.50,1735.00,1628.17,1507.55$, 1139.87. ${ }^{1} \mathrm{H}$ NMR $\left(400 \mathrm{MHz}, \mathrm{CDCl}_{3}\right): \delta 7.23(\mathrm{~d}, J=8.60 \mathrm{~Hz}, 2 \mathrm{H}), 7.18(\mathrm{br} \mathrm{s}, 1 \mathrm{H}), 7.05(\mathrm{~d} J$ $=8.60 \mathrm{~Hz}), 6.85(\mathrm{~d}, J=8.35 \mathrm{~Hz}, 2 \mathrm{H}), 6.72(\mathrm{~s}, 1 \mathrm{H}), 4.30(\mathrm{t}, J=6.22 \mathrm{~Hz}, 2 \mathrm{H}), 4.25(\mathrm{t}, J=6.22$ $\mathrm{Hz}, 2 \mathrm{H}), 3.62$ (s, 2H), 2.25 (s, 6H), $2.02(\mathrm{~m}, 2 \mathrm{H}), 1.63$ (s, 6H). ${ }^{13} \mathrm{C} \mathrm{NMR}(100 \mathrm{MHz}$, $\left.\mathrm{CDCl}_{3}\right): \delta 174.14,169.26,155.00,138.78,137.65,130.46,128.33,126.28,119.11,117.68$, 79.24, 69.52, 61.37, 44.05, 26.28, 25.53, 21.41. HRMS calc. $\mathrm{m} / \mathrm{z}$ for $\left[\mathrm{C}_{23} \mathrm{H}_{28} \mathrm{~N}_{2} \mathrm{O}_{7} \mathrm{Na}\right]^{+}$: 467.1794, found: 467.1841 .

\section{Synthesis of (Z)-2-((2-(4-(2-(3,5-dimethylphenyl)amino)-2-oxoethyl)phenoxy)-2- methylpropanoyl)-peroxy)-1-(pyrrolidin-1-yl)diazene 1-oxide, DD-3}

To a DMF ( $2 \mathrm{~mL}$ ) solution of freshly prepared $\mathrm{O}^{2}$-chloromethyl 1-(pyrrolidin-1-yl)diazen-1ium-1,2-diolate $(0.10 \mathrm{~g}, 0.56 \mathrm{mmol})$, (prepared as previously reported $\left.{ }^{34}\right)$ was added RSR13 $(0.19 \mathrm{~g}, 0.56 \mathrm{mmol})$ in one portion, followed by the addition of cesium carbonate $(0.18 \mathrm{~g}$, $0.56 \mathrm{mmol})$. The mixture was stirred at room temperature for $15 \mathrm{~h}$, and then was diluted with water and extracted with $\mathrm{CH}_{2} \mathrm{Cl}_{2}(10 \mathrm{~mL} \times 3)$. The separated organic phase was combined, washed with brine, dried over $\mathrm{Na}_{2} \mathrm{SO}_{4}$, and concentrated under vacuum to give the crude product, which was further purified by silica gel column chromatography eluting with hexanes/EtOAc (2:1) to yield $0.11 \mathrm{~g}$ of the titled compound as colorless oil with yield of 41\%. HPLC purity: 98.7\%. (Retention time: $5.06 \mathrm{~min} .30 \% \mathrm{H}_{2} \mathrm{O}$ and $70 \% \mathrm{MeCN}$ over 30 min at $254 \mathrm{~nm}$ on Varian C18 column) IR (neat, $\mathrm{cm}^{-1}$ ) $\nu_{\max }: 3307.34,2982.95,1751.57$, 1614.43, 1507.17, 1233.15, 1166.75, 1049.51, 939.61. $\left.{ }^{1} \mathrm{H} \mathrm{NMR} \mathrm{(400} \mathrm{MHz,} \mathrm{CDCl}_{3}\right): \delta 7.17$ (d, $J=8.40 \mathrm{~Hz}, 2 \mathrm{H}), 7.04(\mathrm{~s}, 2 \mathrm{H}), 6.98(\mathrm{br} \mathrm{s}, 1 \mathrm{H}), 6.86(\mathrm{~d} J=8.40 \mathrm{~Hz}, 2 \mathrm{H}), 6.72(\mathrm{~s}, 1 \mathrm{H})$, $5.85(\mathrm{~s}, 2 \mathrm{H}), 3.62(\mathrm{~s}, 2 \mathrm{H}), 3.48(\mathrm{~m}, 4 \mathrm{H}), 2.26(\mathrm{~s}, 6 \mathrm{H}), 1.88(\mathrm{~m}, 4 \mathrm{H}), 1.62(\mathrm{~s}, 6 \mathrm{H}) .{ }^{13} \mathrm{C} \mathrm{NMR}$ (100 MHz, $\left.\mathrm{CDCl}_{3}\right): \delta$ 172.97, 169.00, 154.70, 138.64, 137.48, 130.29, 128.26, 126.25, $119.93,117.54,87.81,79.12,50.66,44.09,25.23,22.91,21.27$. HRMS calc. $\mathrm{m} / \mathrm{z}$ for $\left[\mathrm{C}_{25} \mathrm{H}_{32} \mathrm{~N}_{4} \mathrm{O}_{6} \mathrm{Na}\right]^{+}:$507.2219, found: 507.2241.

\section{Nitric Oxide Release in the Presence of L-cysteine}

Stock solutions of test compounds ( $10 \mathrm{mM}$ in DMSO) were prepared, and $60 \mu \mathrm{L}$ of each compound was added to $5.94 \mathrm{~mL}$ of a mixture of $50 \mathrm{mM}$ potassium phosphate buffer $(\mathrm{pH}$ 7.4) and methanol (1:1, v:v), containing $5 \mathrm{mM} \mathrm{L}$-cysteine. The reaction samples were incubated at $37^{\circ} \mathrm{C}$, and $1 \mathrm{~mL}$ of aliquots were taken at $1,2,4$, and $8 \mathrm{hrs}$, exposed to air for $10 \mathrm{~min}$, and Greiss reagent $(250 \mu \mathrm{L})$ added to each solution. The mixture was allowed to 
stand at $25^{\circ} \mathrm{C}$ for $30 \mathrm{~min}$, and the absorbance of each sample determined at $540 \mathrm{~nm}$. Solutions of $0-100 \mu \mathrm{M}$ sodium nitrite were used to prepare a nitrite absorbance versus concentration curve under the same experimental conditions. The percent nitric oxide released (quantitated as nitrite ion) was calculated from the standard nitrite concentration curve.

\section{Nitric Oxide Release in the Presence of Human Serum}

Stock solutions of test compounds ( $10 \mathrm{mM}$ in DMSO) were prepared, and $30 \mu \mathrm{L}$ of each compound was added to $270 \mu \mathrm{L}$ human serum. The mixture was then made up to a volume of $1.5 \mathrm{~mL}$ containing $0.2 \mathrm{U} / \mathrm{mL}$ Aspergillus nitrate reductase, $50 \mathrm{nM}$ HEPES buffer, $5 \mu \mathrm{M}$ FAD, and $0.1 \mathrm{mM}$ NADPH. The reaction mixture was incubated at $37^{\circ} \mathrm{C}$, and $250 \mu \mathrm{L}$ of aliquots taken at $1,2,4$, and $8 \mathrm{hrs}$, and $2.5 \mu \mathrm{L}$ of lactate dehydrogenase $(1500 \mathrm{U} / \mathrm{mL})$ and 25 $\mu \mathrm{L}$ of $100 \mathrm{mM}$ pyruvic acid added to oxidize any unreacted NADPH, and further incubated for $10 \mathrm{~min}$. Greiss reagent $(275.5 \mu \mathrm{L})$ was then added to each tube, and the mixture allowed to stand at $25^{\circ} \mathrm{C}$ for $30 \mathrm{~min}$. Water $(555 \mu \mathrm{L})$ was added to each reaction mixture, and the absorbance was determined at $540 \mathrm{~nm}$, and \% nitric oxide release was calculated as described above.

\section{Oxygen Equilibrium Curve}

The OEC studies with normal whole blood or clarified $\mathrm{Hb}$ were conducted using multipoint tonometry or Hemox Analyzer (TCS Scientific Corp.) as previously reported ${ }^{55,56}$. Stock solutions of RSR13, DD-1, DD-2, DD-3 were made at $250 \mathrm{mM}$ or $500 \mathrm{mM}$ in DMSO. For the whole blood study, a test compound or DMSO (control) was added to $2 \mathrm{~mL}$ of blood (Hemocrit of $30 \%$ ) at a final drug concentration of $2 \mathrm{mM}$ and incubated at $37{ }^{\circ} \mathrm{C}$. At various time points of 1,2, 4 and $8 \mathrm{hrs}$, aliquots were taken and subjected to OEC analysis using multipoint tonometry.

For the OECs of clarified $\mathrm{Hb}$ lysates from normal whole blood using Hemox Analyzer, aliquot samples $(500 \mu \mathrm{l})$ of $\mathrm{Hb}$ lysates were incubated with RSR-13, DD-1, DD-2, DD-3, or DMSO (control) at a final concentration of $2 \mathrm{mM}$ for up to $8 \mathrm{~h}$. At defined intervals, $50 \mu \mathrm{l}$ aliquots of each sample was mixed with $4.5 \mathrm{ml}$ of $0.1 \mathrm{M}$ potassium phosphate buffer, $\mathrm{pH}$ 7.0, at $25^{\circ} \mathrm{C}$ in the sample cuvette and subjected to OEC analysis.

\section{Structure of DD-1 in Complex with Deoxygenated Hb}

$50 \mathrm{mg} / \mathrm{mL}$ of $\mathrm{Hb}$ and 10 molar excess of DD-1 were mixed together. A small pellet of sodium dithionite was added and the mixture evacuated for 30 minutes to make the deoxyHb solution. Subsequent crystallization (under anaerobic condition) using the batch method as previously described ${ }^{5,54}$ was undertaken using low-salt precipitant of $0.2 \mathrm{M}$ sodium acetate trihydrate, $0.1 \mathrm{M}$ sodium cacodylate trihydrate $\mathrm{pH} 6.5$ and $30 \%$ w/v PEG 8000. Dark purple and rectangular crystals grew to a size of about $0.2 \times 0.3 \times 0.4 \mathrm{~mm}$ in $2-4$ days. X-ray diffraction data was collected at $100 \mathrm{~K}$ with a $\mathrm{R}$-axis IV++ image-plate detector using $\mathrm{CuKa}$ $\mathrm{x}$-rays $\left(\lambda=1.54 \AA\right.$ ) from Rigaku Micro-Max ${ }^{\mathrm{TM}}$-007 $\mathrm{x}$-ray source equipped with varimax confocal optics (Rigaku, The Woodlands, TX) operating at $40 \mathrm{kv}$ and $20 \mathrm{~mA}$. Prior to use, the crystals were washed in a cryo-protectant solution containing mother liquor $(45-55 \mu \mathrm{L})$ 
and glycerol $(20 \mu \mathrm{L})$ and then flash frozen. The collected data sets were processed with the $\mathrm{d}^{*} T R E K$ software program and the CCP4 suite of programs.

The structure was solved by molecular replacement using the T-state native deoxyHb structure (PDB code 2DN2) as the search model. One Cycle of refinement with CNS and COOT $^{57,58}$ identified two-symmetry-related bound compounds that appeared to be RSR13 at the central water cavity of the Hb, and two RSR13 molecules were built in the density. The difference map also showed a two-atom bound ligands at the a-hemes distal positions but not the $\beta$-hemes, and NO were built into the densities. Also, included in the model were two nitrate ions bound to the side-chains of the two $\beta$ His97. Further refinement of the model, suggested that the bound effector at the central water cavity could possibly be a mixture of RSR13, DD-1, and RSR13- $\mathrm{CH}_{2} \mathrm{CH}_{2} \mathrm{OH}$. However, in addition to RSR13, only DD-1 was included in the model and only at one of the symmetry-related positions where it was relatively well-defined. Several water molecules and a cacodylate molecule bound at the $\beta$-cleft were added and the structure refined to final Rfactor/Rfree of $19.8 / 25.3 \%$. The coordinate has been deposited at the PDB with accession code of 5E29.

\section{Sample Preparation of DD-1 and DD-3 with Buffer or DMSO for UPLC-MS Analysis}

$20 \mu \mathrm{L}$ of the test compound ( $20 \mathrm{mM}$ in DMSO) was mixed with $480 \mu \mathrm{L}$ of buffer $(50 \mathrm{mM}$ of tris buffer containing $0.5 \mathrm{mM}$ of EDTA, $\mathrm{pH} 8.6$ ), and the mixture incubated at room temperature or $37^{\circ} \mathrm{C}$ for 1 day, and the sample filtered prior to UPLC-MS analysis. Another DMSO sample preparation without the buffer was also used for UPLC-MS analysis after incubation at $37^{\circ} \mathrm{C}$ for 1 day and diluted with $500 \mathrm{uL}$ with acetonitrile.

\section{Sample Preparation of DD-1 and DD-3 with L-cysteine or Serum for UPLC-MS Analysis}

$20 \mu \mathrm{L}$ of the test compound ( $20 \mathrm{mM}$ in DMSO) was mixed with $480 \mu \mathrm{L}$ of buffer containing L-cysteine (50 mM phosphate buffer, $\mathrm{pH} 7.4$ and $\mathrm{MeOH}$ in one to one ratio containing 5 mM L-cysteine) or with $90 \mu \mathrm{L}$ of serum, $25 \mu \mathrm{L}$ of 1 M HEPES buffer, and $365 \mu \mathrm{L}$ of water. The mixture was then incubated at room temperature or $37^{\circ} \mathrm{C}$ for 1 day, and the sample filtered prior to UPLC-MS analysis.

\section{Sample Preparation of DD-1 with Solution Mimicking the Crystallization Condition for UPLC-MS Analysis}

DD-1 (4 mg) dissolved in $100 \mu \mathrm{L}$ of DMSO was added to $1 \mathrm{~mL}$ of the crystallization buffer $(0.2 \mathrm{M}$ sodium acetate trihydrate, $0.1 \mathrm{M}$ sodium cacodylate trihydrate $\mathrm{pH} 6.5$ and $30 \% \mathrm{w} / \mathrm{v}$ PEG 8000 ), followed by addition of $\sim 1 \mathrm{mg}$ of sodium dithionite. The mixture was incubated at room temperature for 2 days or 8 days, and the sample filtered prior to LC-MS analysis.

\section{Sample Preparation of DD-1 and DD-3 with Clarified Hb or Whole Blood or bovine serum albumin for UPLC-MS Analysis}

$10 \mu \mathrm{L}$ of DD-1 and DD-3 solution (20 mM in DMSO) were each mixed with either $90 \mu \mathrm{L}$ of hemoglobin ( $2 \mathrm{mM}$ in $50 \mathrm{mM}$ tris buffer containing $0.5 \mathrm{mM}$ EDTA, $\mathrm{pH}$ 8.6) or $90 \mu \mathrm{L}$ of the whole blood (30\% HCT) or $90 \mu \mathrm{L}$ of BSA ( $2 \mathrm{mM}$ in $50 \mathrm{mM}$ of tris buffer and $0.5 \mathrm{mM}$ of EDTA) and incubated at room temperature or $37^{\circ} \mathrm{C}$ for $16 \mathrm{~h} .500 \mu \mathrm{L}$ of acetonitrile was 
added to each sample to precipitate the protein constituents. After centrifugation, the supernatant solutions were taken for the UPLC-MS analysis.

\section{General UPLC-MS Protocol}

The UPLC-MS analysis was performed using a Waters Acquity H-Class UPLC which is connected to a PDA detector and a Waters Acquity TQD detector. The column used was a Waters Acquity UPLC BEH C18 $1.7 \mu \mathrm{m}, 2.1 \times 50 \mathrm{~mm}$, with a Vanguard precolumn attached. Solvent A consisted of 90:10 water:acetonitrile with $0.01 \%$ formic acid and $0.1 \mathrm{mM}$ hexylamine, while solvent B consisted of 90:10 acetonitrile:water with $0.01 \%$ formic acid with $0.1 \mathrm{mM}$ hexylamine. A gradient run was performed such that solvent $B$ was increased from $0 \% \mathrm{~B}$ to $100 \% \mathrm{~B}$ from time $0-7$ mins, followed by 5 minute wash at $100 \% \mathrm{~B}$ and then a return and re-equilibration at $100 \% \mathrm{~A}$ in the next 3 mins. $10 \mu \mathrm{L}$ of sample was injected per run. The eluent of the column was connected to a PDA UV detector which scanned from 250-350 nm and a 2D channel of $280 \mathrm{~nm}$ was set. The eluent was then introduced into the TQD detector. The TQD detector was set at positive ionization mode with a capillary voltage of $3.20 \mathrm{kV}$, cone voltage of $20 \mathrm{~V}$, extractor voltage of $3 \mathrm{~V}$, and RF lens voltage of $0.1 \mathrm{~V}$. The source temperature was set at $150{ }^{\circ} \mathrm{C}$, while the desolvation temperature was set at $350{ }^{\circ} \mathrm{C}$ and the desolvation and cone gas flows were set at 650 and $50 \mathrm{~L} / \mathrm{hr}$ respectively. Scans were made from $100-700 \mathrm{~m} / \mathrm{z}$ with scan duration of 0.5 seconds to obtain mass spectra at different time points.

\section{Results and Discussion}

\section{Chemistry}

In this study, we incorporated the well-established NO donor group, namely nitrooxyalkyl or 1-(pyrrolidin-1-yl)diazen-1-ium-1,2-diolate ${ }^{33}$ onto RSR13, resulting in the compounds DD-1, DD-2 and DD-3 (Fig. 1). The synthetic routes for the preparation of the nitrooxyalkyl derivatives, DD-1 and DD-2, and the diazen-1-ium-1,2-diolate derivative, DD-3 are shown in Schemes 1 and 2, respectively. For compounds DD-1 and DD-2, the synthesis was achieved by coupling RSR13 with bromoethyl nitrate or bromopropyl nitrate, respectively, which was prepared from the nitration of bromoethanol or bromopropanol. Compound DD-3 was prepared through the coupling of RSR13 with $\mathrm{O}^{2}$-chloromethyl 1-(pyrrolidin-1yl)diazen-1-ium-1,2-diolate, which was synthesized utilizing a published method ${ }^{59}$.

\section{The Prodrugs are Capable of Releasing NO}

The key requirement for any therapeutic effectiveness of the NO-releasing ester prodrugs is their ability to undergo biotransformation in-vivo, either enzymatically or non-enzymatically to release the parent RSR13 and NO. We therefore first evaluated DD-1, DD-2, and DD-3 in-vitro for their NO-releasing ability with both L-cysteine and serum. At various incubation times (1, 2, 4 and $8 \mathrm{hr}$ ) of the compounds with L-cysteine or human serum at $37^{\circ} \mathrm{C}$, aliquots were added to Griess reagent to quantify the released $\mathrm{NO}$ in the form of nitrite ion $\left(\mathrm{NO}_{2}^{-}\right)$as previously reported ${ }^{34,60}$. Results are expressed as percentage of $\mathrm{NO}$ released relative to the theoretical maximum release of one mol of NO/mol of DD- 1 or DD-2, and $2 \mathrm{~mol}$ of $\mathrm{NO} / \mathrm{mol}$ of DD-3, and are shown in Table 1 and Figure 2. With L-cysteine, after $1 \mathrm{hr}$, the three tested 
compounds DD-1, DD-2 and DD-3 resulted in \%NO release of 3.8, 3.5 and 1.8, respectively which gradually increased to 9.3, 5.3 and 5.1, respectively at 8 hrs (Fig. 2A).

With serum (containing esterases) ${ }^{34}$, formation of nitrite with DD-1 was almost constant at $\sim 9.5 \%$ during the $8 \mathrm{hr}$ experiment, while DD-2 increased from $2.3 \%$ to $7.0 \%$ at $2 \mathrm{hrs}$ and decreased to $5.1 \%$ at 8 hrs (Fig. 2B). In contrast, the diazen-1-ium-1,2-diolate prodrug, DD-3, showed substantial nitrite formation at $1 \mathrm{hr}(41.5 \%)$ in serum, which increased to $50.6 \%$ in 8 hrs (Fig. 2B). As expected, RSR13 did not show any formation of nitrite (not shown in the Table).

In general, the nitrooxyalkyl prodrugs, DD-1 and DD-2, appear to produce more NO and more rapidly than the diazen-1-ium-1,2-diolate prodrug, DD-3 with L-cysteine, while the opposite is true with serum, consistent with previous findings of these two classes of NOreleasing moieties ${ }^{33}$. Among the nitrooxyalkyl prodrugs, DD-1 (with the shorter nitrooxyalkyl chain) released more NO than DD-2 (with the longer nitrooxyalkyl chain) with both L-cysteine and serum, especially in the former matrix. These findings indicate that invivo (serum) rapid, enzymatic ester hydrolysis is the major mechanism of NO release in blood, favoring DD-3, while the chemical NO release from L-cysteine favors the nitrooxyalkyl prodrugs, particularly DD-1. A notable pharmacologic advantage of diazen-1ium-1,2-diolate prodrugs is that their use is not likely to lead to clinical nitrate tolerance development compared to the nitrooxyalkyl prodrugs, because NO-release by the latter is dependent on metabolic activation that decreases in efficiency upon continued use ${ }^{34,61-63}$. These observations suggest that in-vivo, the diazen-1-ium-1,2-diolate prodrug may release more NO than the nitrooxyalkyl prodrugs, i.e. have superior NO-releasing pharmacologic property than their nitrooxyalkyl prodrug counterparts.

\section{The Prodrugs Decrease $\mathrm{Hb}$ Affinity for $\mathrm{O}_{2}$}

Biotransformation of the DD compounds is anticipated to release RSR13, which in-vivo is expected to bind to $\mathrm{Hb}$ and decrease $\mathrm{O}_{2}$-affinity. We therefore conducted time-dependent (1, 2, 4 and 8 hrs) in-vitro OEC studies to determine the effect of RSR13, DD-1, DD-2 and DD-3 at concentrations of $2 \mathrm{mM}$ on the $\mathrm{Hb}$ affinity for $\mathrm{O}_{2}$ in normal human blood (Hemocrit of $\sim 30 \%$ ) at $37^{\circ} \mathrm{C}$ using multipoint tonometry as previously described ${ }^{55,56}$. Results of the whole blood assay are tabulated in Table 2, and also shown in Figure 3A. The $\Delta \mathrm{P}_{50}$ of RSR13 increased from $25.4 \mathrm{mmHg}$ at $1 \mathrm{hr}$ to a maximum of $32.1 \mathrm{mmHg}$ at $2 \mathrm{hrs}$, and then gradually decreased to $26.1 \mathrm{mmHg}$ after $8 \mathrm{hrs}$. DD- 1 increased the $\mathrm{P}_{50}$ by $10 \mathrm{mmHg}$ at $1 \mathrm{hr}$, peaking at $2 \mathrm{hrs}$ with $\Delta \mathrm{P}_{50}$ of $15.2 \mathrm{mmHg}$, and gradually decreasing to $11.5 \mathrm{mmHg}$ after 8 hrs. DD-2 and DD-3 showed $\Delta \mathrm{P}_{50}$ of 6.3 and $4.9 \mathrm{mmHg}$ at $1 \mathrm{hr}$, respectively, which gradually increased and peaked at $8 \mathrm{hrs}$ with $\Delta \mathrm{P}_{50}$ of $20.7 \mathrm{mmHg}$ and $21.7 \mathrm{mmHg}$, respectively. At their peak effects, $\mathrm{RSR} 13\left(\Delta \mathrm{P}_{50}\right.$ of $32.1 \mathrm{mmHg}$ at $\left.2 \mathrm{hrs}\right)$ is the most potent, followed by DD-3 and DD-2 ( $\Delta \mathrm{P}_{50}$ of $\sim 21 \mathrm{mmHg}$ at $8 \mathrm{hrs}$ ), and lastly DD-1 ( $\Delta \mathrm{P}_{50}$ of $\sim 15$ $\mathrm{mmHg}$ at $2 \mathrm{hrs}$ ). It appears from the OEC study that the allosteric property of the diazen-1ium-1,2-diolate prodrug is relatively superior to its nitrooxyalkyl prodrug counterparts.

We further evaluated the allosteric activity of RSR13, DD-1, DD-2, and DD-3 (2 mM concentration) with clarified $\mathrm{Hb}$ (devoid of any other proteins, enzymes, plasma and cell membranes), also in a time-dependent fashion (Table 3, Fig. 3B). For the first four hours, 
there was very little, if significant at all, decrease in $\mathrm{Hb} \mathrm{O}_{2}$-affinity in the presence of the prodrugs, however at $8 \mathrm{hrs,} \mathrm{DD-1,} \mathrm{DD-2} \mathrm{and} \mathrm{DD-3} \mathrm{showed} \mathrm{decrease} \mathrm{in} \mathrm{Hb} \mathrm{O}_{2}$-affinity by $1.25 \mathrm{mmHg}, 1.7 \mathrm{mmHg}$, and $0.81 \mathrm{mmHg}$ respectively. These results contrast with RSR13 which maintained an increase of $\mathrm{P}_{50}$ shift of $\sim 4 \mathrm{mmHg}$ during the $8 \mathrm{hr}$ experiment. (Table 3, Fig. 3B). Clearly, whole blood, plasma esterases and possibly other enzymes are able to hydrolyze the carboxylate ester group of the prodrugs releasing RSR13, which is expected to bind to the central water cavity of the Hb, stabilizing the T-state and decrease the protein affinity for oxygen ${ }^{2,5}$. In contrast, such hydrolytic process may not occur with clarified $\mathrm{Hb}$ to release RSR13, consistent with UPLC-MS studies (vide infra). Thus the observed allosteric effect with free $\mathrm{Hb}$, albeit delayed is most likely due to direct prodrug binding to $\mathrm{Hb}$. The data also suggests that unlike RSR13, these prodrugs react very slowly and weakly with $\mathrm{Hb}$, consistent with the crystallographic and UPLC-MS studies (vide infra).

\section{Structure of Deoxygenated Hb Co-crystallized with DD-1}

We have solved the crystal structure of deoxygenated $\mathrm{Hb}$ that was co-crystallized with DD-1 to $1.85 \AA$. To obtain the crystals, deoxygenated $\mathrm{Hb}$ (made by adding a small pellet of sodium dithionite to $\mathrm{Hb}$ ) was incubated with $\mathrm{DD}-1$, and the complex solution crystallized using lowsalt precipitant $(0.2 \mathrm{M}$ sodium acetate trihydrate, $0.1 \mathrm{M}$ sodium cacodylate trihydrate $\mathrm{pH} 6.5$ and 30\% w/v PEG-8000) and the batch method, all under anaerobic condition as previously described $^{5,54}$. The structure was determined using molecular replacement with the high-salt T-state deoxyHb structure (PDB code 2DN2) ${ }^{64}$. Detailed crystallographic data, including data collection and refinement is summarized in Table 4. The final tetrameric Hb structure contained a pair of RSR13 and one molecule of DD-1 (RSR13- $\left.\mathrm{CH}_{2} \mathrm{CH}_{2} \mathrm{ONO}_{2}\right)$, all bound at the central water cavity (Fig. 4). Another DD-1 hydrolysis product, RSR13- $\mathrm{CH}_{2} \mathrm{CH}_{2} \mathrm{OH}$ may also be part of the central water cavity bound ligands, although it was not included in the refinement. We also observed two NO molecules bound to the a-heme irons, two nitrate molecules bound to the $\beta$ His97 ( $\beta 1$ His97 and $\beta 2 \mathrm{His} 97$ ) imidazoles, and a cacodylate molecule (from the precipitant used for crystallization) bound to the dyad axis of the $\beta$-cleft (Fig. 4). As will be shown later, the sodium dithionite used to deoxygenate the $\mathrm{Hb}$ for crystallization most likely led to formation of RSR13 and RSR13- $\mathrm{CH}_{2} \mathrm{CH}_{2} \mathrm{OH}$, and apparently the $\mathrm{NO}-\mathrm{Hb}$ adducts. The structure reported here will hence be referred to as bisligated T-state HbNO.

The quaternary structure of the bis-ligated T-state $\mathrm{HbNO}$ is similar to the previously published T-state $\mathrm{Hb}$ structure (PDB code 2DN2; RMSD $0.45 \AA$ ) or the tetra-ligated T-state HbNO structure (PDB code 1RPS; RMSD $0.38 \AA$ ), however, as will be discussed later, there are several notable localized structural differences between these structures.

\section{DD-1 and its Hydrolysis Products Bind at the Central Water Cavity of DeoxyHb}

DD-1 appears to bind to the central water cavity of deoxyHb as a mixture of DD-1 (RSR13$\mathrm{CH}_{2} \mathrm{CH}_{2} \mathrm{ONO}_{2}$ ), RSR13- $\mathrm{CH}_{2} \mathrm{CH}_{2} \mathrm{OH}$ and RSR13. During the initial refinements of the structure, we modeled a pair of RSR13 molecules in a symmetry-related manner into the difference electron density map at the central water cavity of $\mathrm{Hb}$ (Fig. 5A) as previously reported ${ }^{5}$. Subsequent refinement of the model suggested the ligand density (Fig. 5A and B) to be actually a mixture of DD-1 and RSR13, and possibly RSR13- $\mathrm{CH}_{2} \mathrm{CH}_{2} \mathrm{OH}$, consistent 
with UPLC-MS analysis (vide infra). Two molecules of RSR13, bound in a symmetryrelated fashion to the $\alpha 1 \alpha 2 \beta 1$ and $\alpha 2 a 1 \beta 2$ subunits, respectively, and one molecule of DD-1 occupying almost the same position as the RSR13 a 1a2 $\beta 1$ bound molecule (each refined at $40 \%$ occupancy) were modeled and refined. There was no observable density for the nitrooxyethyl moiety at the $a 2 a 1 \beta 2$ binding site, and therefore only RSR 13 was refined at this site at $80 \%$ occupancy. Thus, despite the large amount of DD-1 used for the cocrystallization experiment (10 molar excess to $\mathrm{Hb}$ ), the bound compounds showed relatively weak density. This observation is in contrast to our previous structural study of deoxyHb in complex with RSR13 (1:5 molar ratio) that showed very strong RSR13 electron density 5 . Notably, other analogs of RSR13 that have amino acid substitution at the carboxylate are also characterized by weak density and/or significantly less allosteric potency than RSR13 ${ }^{65,66}$. As will be discussed later, UPLC-MS analysis of the crystallization solution showed DD-1 to predominate the mixture, which is at least 3-fold excess over RSR13 and RSR13- $\mathrm{CH}_{2} \mathrm{CH}_{2} \mathrm{OH}$ combined, suggesting that the binding site may have a weaker affinity for DD-1, and thus explaining the weak presence of the effector in the structure. This observation is also the most likely explanation why the NO-releasing prodrugs showed very weak and delayed allosteric effect when incubated directly with clarified $\mathrm{Hb}$.

The mode of interaction of RSR13 with $\mathrm{Hb}$, and the mechanism underlying RSR13 allosteric activity has been well-elucidated ${ }^{2,5}$. Except for additional interactions by the nitrooxyethyl moiety of DD-1, the almost superposed compounds, DD-1 and RSR13 bind deoxyHb in a similar fashion, interacting with the a1-, a2- and $\beta 1$-subunit ${ }^{5}$ (Fig. 5). Only RSR 13 was modeled at the opposite a 2 a $1 \beta 2$ binding site. At the a $1 a 2 \beta 1$ binding site, the carboxylate of RSR13 or the ester carbonyl oxygen of DD-1 forms inter-subunit watermediated hydrogen bond interaction with the amine of a $2 \operatorname{Arg} 141$ (Fig. 5C). The methylpropionate and phenyl groups of DD-1/RSR13 make several intra- and inter-subunit hydrophobic interactions with $\beta 1$ Tyr35, $\beta 1$ Trp37, $\beta 1$ Leu105, a2Thr137, a2Tyr 140 and a2Pro95, while the amide oxygen or nitrogen makes direct or water-mediated intra-subunit hydrogen bond interactions with the side-chains of a 1Lys99, $\beta 1$ Tyr35, and $\beta 1$ Asn 108 . The dimethylbenzene ring makes hydrophobic intra-subunit interactions with a1Phe36, a1Lys99, a1His103, a1Leu100, and $\beta 1$ Asn108. The side-chain of $\beta 1$ Asn108 is also engaged in hydrogen-bond interaction with the pi-electrons of the dimethylbenzene ring. The nitrate moiety of DD-1 is further involved in direct or water-mediated intra-subunit hydrogen-bond interactions with a 1Thr134, a 1Ala30, and a 1Ser131. As noted above, we did not model DD-1 at the a 2 a $1 \beta 2$ RSR13 binding site because of weak density where the nitrooxyethyl moiety was supposed to be; rather water molecules were placed in those densities. Nonetheless, we observe similar RSR13 symmetry-related interactions at the a $2 a 1 \beta 2$ binding site as described above for the a $1 a 2 \beta 1$ bound RSR13. The DD-1/RSR13 interactions, as previously noted for RSR 13 and several of its analogs ${ }^{2,5,65,66}$, serve to tie the deoxyHb subunits together stabilizing the T-state, reducing allosteric interactions among the subunits and decreasing $\mathrm{Hb}$ affinity for $\mathrm{O}_{2}$. The structural study also suggests that in-vivo biotransformation of DD-1 to yield RSR13 would likely result in RSR13 binding to the protein to effect its allosteric activity, consistent with the OEC studies. Although, we did not determine the deoxyHb structures complexed with DD-2 or DD-3, we expect the respective structures to show bound RSR13, NO and nitrate molecules as described above for the DD-1 
structure. We also expect the intact DD-2 and DD-3 to be able to bind to the allosteric site as described for DD-1, however, the bulky nature of the DD-3 pyrrolidin-1-yl)diazen-1-

ium-1,2-diolate moiety would introduce steric interaction and thus decrease its affinity to the protein compared to DD-1 or DD-2. Nonetheless, direct binding of all the prodrugs to the $\mathrm{Hb}$ is expected to be slow and weak as observed with the OEC study with clarified $\mathrm{Hb}$.

\section{The $a$-Hemes but not the $\beta$-Hemes are Coordinated with NO}

Nitric oxide has been shown structurally to interact with the heme irons in both deoxyHb and oxyHb to form $\mathrm{HbNO}^{48,49}$ and/or to interact with $\beta \mathrm{Cys} 93$ of oxyHb to form $\mathrm{HbSNO}^{53}$. In the structure reported here, NO likely produced from DD-1 hydrolysis to RSR13 and/or RSR13- $\mathrm{CH}_{2} \mathrm{CH}_{2} \mathrm{OH}$ binds to the distal side of the two a-heme irons, forming a bis-ligated T-state $\mathrm{HbNO}$ derivative structure (Fig. 6A and B). It is also quite conceivable that, nitrite, as a result of the hydrolysis of DD-1 initially bound to the heme to form HbONO, was subsequently reduced to $\mathrm{HbNO}$ by the sodium dithionite. A similar method has been used to obtain the nitrosyl derivative of $\mathrm{Hb}^{49,67}$. We found no structural evidence for a bound $\mathrm{NO}$ at $\beta C y s 93$ in our structure, which is consistent with modification of this residue only in the Rstate where the cysteine is exposed ${ }^{50,68}$. Chan et al., recently published a T-state human $\mathrm{HbNO}$ structure with all four hemes coordinated with $\mathrm{NO}$ (tetra-ligated T-state $\mathrm{HbNO}$ ); 48 however, unlike our bis-ligated T-state $\mathrm{HbNO}$ structure, where the crystal was obtained from solution, the tetra-ligated $\mathrm{NO}$ structure was obtained by exposing already formed T-state crystals with $\mathrm{NO}$ gas. A tetra-ligated R-state $\mathrm{HbNO}$ structure has also been reported by Richter-Addo and co-workers ${ }^{49}$. It is interesting that despite $\mathrm{Hb}$ high affinity for $\mathrm{NO}^{69,70}$, our structure only showed ligation at the two a-hemes. The isolation of this bis-ligated $\mathrm{HbNO}$ structure, the first of its kind to be reported, likely occurred as a result of the bound RSR13 decreasing the protein affinity for the ligand, and perhaps, coupled with the fact that only a small quantity of NO might have been released during the hydrolysis of DD-1 as suggested by our NO-release study.

In the published tetra-ligated $\mathrm{T}$-state $\mathrm{HbNO}$ structure ${ }^{48}$, binding of $\mathrm{NO}$ has resulted in a complete breakage of the proximal Fe-N(His87) bond (4.06 A) in the a-hemes, but not in the $\beta$-hemes. Interestingly, the corresponding $\alpha$-heme bond in our bis-ligated T-state $\mathrm{HbNO}$ is also broken but with a distance of $3.3 \AA$ between the iron and the proximal histidine as shown by the lack of overlapping density between the iron and the histidine (Fig. 6B). In contrast, $\mathrm{NO}$ ligation of the a-heme in the tetra-ligated $\mathrm{R}$-state $\mathrm{HbNO}$ structure did not break the Fe-N(His87) bond (1.96 $)^{49}$. The broken or weakened Fe-N(His87) bond in the tetra-ligated and bis-ligated T-state $\mathrm{HbNO}$ structures have resulted in the displacement of the aFe atom toward the distal side of the porphyrin $(0.25 \AA$ and $0.16 \AA$, respectively), while in the R-state structure the iron is centered in the heme plane. These structural observations are consistent with Perutz's stereochemical theory that suggested that ligation of T-state $\mathrm{Hb}$ is opposed by tension at the a-heme groups leading to rupture of the Fe-N(His87) bond ${ }^{71-74}$. As found in the tetra-ligated T-state $\mathrm{HbNO}$ structure, we also observed a water-mediated hydrogen bond interactions between the proximal histidine and $a$ Tyr $140^{48}$ (Fig. 6A and B), which has been proposed to stabilize the position of the cleaved Fe-N(His87) bond ${ }^{75}$. The $\mathrm{Fe}-\mathrm{N}$ bond and $\mathrm{Fe}-\mathrm{N}-\mathrm{O}$ angle in the bis-ligated $\mathrm{T}$-state $\mathrm{HbNO}$ were not restrained during refinement, resulting in a Fe-N distance of $1.7 \AA$, N-O distance of $1.13 \AA$ and FeN-O angle 
of $144^{\circ}$. This compares with $1.7 \AA, 1.13 \AA$ and $138^{\circ}$, respectively in the tetra-ligated T-state HbNO structure ${ }^{48}$, and $1.8 \AA, 1.18 \AA$ and $138^{\circ}$, respectively in the tetra-ligated R-state HbNO structure ${ }^{49}$. The proximal aHis58 side-chain makes $3.2 \AA$ hydrogen-bond interactions with both the oxygen and nitrogen of the NO ligand that compare with $3.35 \AA$ and $3.4 \AA$, in the tetra-ligated T-state HbNO structure, and $2.7 \AA$ and $2.8 \AA$ in the tetraligated R-state $\mathrm{HbNO}$ structure, respectively.

Unlike the previous T-state and R-state HbNO structures that showed ligation of all hemes with $\mathrm{NO}$, none of the $\beta$-hemes in our structure is ligated with $\mathrm{NO}$, and remains 5-coordinate with an Fe-N(His92) bond distance of $2.05 \AA$ (Fig. 6C) which compares with $2.25 \AA$ and 2.0 $\AA$ for the tetra-ligated T-state and R-state HbNO structures, respectively. Expectedly, the $\beta \mathrm{Fe}$ is displaced toward the distal side of the porphyrin plane by $0.15 \AA$ in the bis-ligated T-state HbNO structure.

A hallmark of $\mathrm{Hb}$ allosterism is the positions of the following heme environment structures: EF-corner, F-helix and FG corner (Fig. 7A and B). The T to R transition moves these structures toward the a $1 \beta 2(\alpha 2 \beta 1)$ dimer interface and/or the central water cavity, resulting in the relaxation of the strain at the $\mathrm{Fe}-\mathrm{N}$ (proximal histidine) bond with a concomitant increase in $\mathrm{Hb}$ oxygen affinity, and vice versa ${ }^{73,76}$. We note that in the a-subunits of the tetra-ligated and bis-ligated HbNO structures, the EF-corner (residues 71-74), F-helix (7590) and FG corner (91-97) are similarly positioned, but interestingly enough, even though the a-hemes are ligated, these heme structures are further removed from their counterparts in the ligated R-state $\mathrm{HbNO}$ structure when compared to those of the un-liganded native Tstate structure (Fig. 7B). This suggests a more tense a-heme environment in the T-state $\mathrm{HbNO}$ structures when compared to the unliganded T-state structure, consistent with the observed ruptured Fe-N(His87) bonds in the liganded structures. Similar finding has been reported for the crystal structure of T-state cyanomethemoglobin, which is also characterized by a ruptured Fe-N(His87) bond ${ }^{71}$.

We also found significant differences in the positions of EF-corner (residues 78-79), F-helix (80-95) and FG corner (96-103) structures at the $\beta$-heme. As expected, the EF-corner, Fhelix and FG corner of tetra-ligated R-state $\mathrm{HbNO}$ (with bound $\beta$-heme ligand) are the most relaxed. The EF-corner, F-helix and FG-corner of the tetra-ligated T-state HbNO (with bound $\beta$-heme ligand) are closer to their counterparts in the R-state HbNO structure, while those of bis-ligated T-state $\mathrm{HbNO}$ and native T-state crystal structures (without bound ligands at the $\beta$-hemes) are close to each other but furthest away from the R-state structure (Fig. 7B).

Crystallographic lattice contacts in the tetra-ligated $\mathrm{HbNO}$ structure were proposed to be the stabilizing factor for preventing crystalline T-state from transitioning to the R-state when the crystal was exposed to NO gas to form the nitrosylHb derivative ${ }^{48}$. In contrast, the bound RSR13 in our structure, as was previously proposed for inositol hexaphosphate (IHP) bound nitrosylHb $\mathrm{H}^{77}$ is providing the stabilization force for preventing the T-R transition with NO ligation. Since NO reacts extremely fast with heme ${ }^{69,70}$ and dissociates very slowly ${ }^{78,79}$, it is not surprising that all four hemes of the previously reported $\mathrm{HbNO}$ crystal structures, including the T-state are ligated with $\mathrm{NO}^{48,49}$. Significant presence of tetra NO-ligation $\mathrm{Hb}$ 
in vivo could be detrimental to the protein's primary function of binding and transporting oxygen; expectedly, under physiological condition only $0.1 \%$ of the total $\mathrm{Hb}$ is in the nitrosyl form ${ }^{80}$. As noted by Yonetani and co-workers, NO ligation of the heme in-vivo appears to occur exclusively at the a-hemes, allowing the nitrosylHb derivative to deliver oxygen to tissues as efficiently as native $\mathrm{Hb}^{81}$. Gladwin et al. also reported that $\mathrm{Hb}$-mediated nitrite reduction proceeds at approximately the $\mathrm{P}_{50}$ where half the $\mathrm{Hb}$ is oxygen-bound ${ }^{82,83}$. Our bis-ligated T-state HbNO structure appears to capture for the first time the physiological nitrosylHb species, providing atomic level insights into how partially NO-ligated $\mathrm{Hb}$ (at the a-heme) may function to bind and transport oxygen. The exclusive ligation of the a-heme in our structure is also consistent with sequential ligation of the heme, starting with the less sterically hindered $a$-heme as proposed by Perutz ${ }^{73,74,76,84,85}$. Finally, the observation that binding of RSR13 to T-state Hb seems to prevent NO from coordinating to all four hemes has important medicinal implication as RSR13 could serve a useful purpose in decreasing $\mathrm{Hb}$ affinity for NO, and thus increasing local NO bioavailability. In fact, RSR13 has been proposed as a potential agent to enhance the bioavailability of gases interacting with $\mathrm{Hb}$, e.g., $\mathrm{CO}, \mathrm{NO}, \mathrm{H}_{2} \mathrm{~S}$, etc. by reducing their binding with native hemoglobin and/or hemoglobin-based oxygen carriers (HBOCs) ${ }^{86}$.

A Nitrate Molecule Binds at $\beta$ His97-Another novel finding of the crystallographic study is a bound nitrate at the two $\beta$ His97 side-chains (Fig. 8). The exact identity of the bound compound is uncertain, whether it is a nitrate ion or $\mathrm{HOCH}_{2} \mathrm{CH}_{2} \mathrm{ONO}_{2}$, either could presumably be formed during the hydrolysis of DD-1. Each $\beta$ His97 binding site shows a strong electron density overlapping the imidazole of $\beta$ His97 that fits a 4-atom nitrate but not big enough to fit $\mathrm{HOCH}_{2} \mathrm{CH}_{2} \mathrm{ONO}_{2}$, necessitating modeling of $\mathrm{NO}_{3}$ into the density (Fig. $8 \mathrm{~A}$ and $\mathrm{B})$. One of the nitrate oxygen makes a strong hydrogen-bond interaction with the side-chain of $\beta$ His97 ( 2.3 $\AA$ ). Binding of the nitrate to $\beta$ His97 induces a conformational change in the vicinity of the binding site. In T-state structures, including native, RSR13 Tstate complex, tetra-ligated T-state $\mathrm{HbNO}$, as well as classical R-state structure, the sidechain of aHis45 makes strong intra-subunit hydrogen-bond interaction with the a-heme propionate (Fig. 8C). The significance of this interaction if any has not been reported. Interestingly, in the bis-ligated T-state HbNO structure, this interaction is either broken with the imidazole of aHis 45 rotated $\sim 180^{\circ}$ to make a hydrogen-bond contact with the bound nitrate at the $\beta 1 \mathrm{His} 97$ site (Fig. $8 \mathrm{C}$ ) or weakened at the $\beta 2 \mathrm{His} 97$ site.

The question we pose is whether the bound nitrate is an artifact or perhaps reveals a possible role of $\beta$ His 97 and aHis 45 for nitrate regulation, providing an interesting alternative biological pathway of $\mathrm{Hb}$ preserving NO bioactivity. Similar adduct formation between $\beta C y s 93$ of oxyHb and $\mathrm{NO}^{50,52}$ has been proposed, although not without controversy, as a way of conserving $\mathrm{NO}$ that is released from $\mathrm{Hb}$ to hypoxic tissue during the transition to the T-state ${ }^{68,87}$. Nitrated lipids ${ }^{88-90}$ have also been proposed as NO storage and/or transport species, which eventually gets converted to NO. However, we could not find in the literature any mention or reported study of a nitrate binding to any specific $\mathrm{Hb}$ amino acid, although as noted by Thatcher et al., apart from the Fe-heme site, $\mathrm{Hb}$ may also have a role in direct interaction with NO containing compounds, including organic nitrites, nitrosothiols, and nitrates, providing the 3 -electrons required for nitrate reduction to $\mathrm{NO}^{60}$. 


\section{The Prodrugs form Degradation Products in the Presence of Different Matrices Mechanism of their Biotransformation}

To gain insight into biotransformation of the NO-releasing prodrugs, as well as their possible mechanism of pharmacologic activity, we used UPLC-MS to follow their reaction products in the presence of different matrices (DMSO, buffer, L-cysteine, sodium dithionite, serum, bovine serum albumin, $\mathrm{Hb}$ or whole blood) that mimic the various study conditions. When incubated with DMSO alone or buffer alone (50 $\mathrm{mM}$ of TRIS and $0.5 \mathrm{mM}$ of EDTA) or buffer with bovine serum albumin for 16 or $24 \mathrm{hrs,} \mathrm{the} \mathrm{compounds,} \mathrm{including} \mathrm{RSR13}$ showed no observable degradation, either at $37^{\circ} \mathrm{C}$ (Figs. S1 and S2) or at room temperature (not shown). When DD-1 is incubated in the presence of L-cysteine at $37^{\circ} \mathrm{C}$ (mimicking the NO releasing study) for $24 \mathrm{hrs,} \mathrm{we} \mathrm{observed} \mathrm{three} \mathrm{main} \mathrm{compounds;} \mathrm{DD-1} \mathrm{(RSR13-}$ $\mathrm{CH}_{2} \mathrm{CH}_{2} \mathrm{ONO}_{2}$ ), $\mathrm{RSR} 13-\mathrm{CH}_{2} \mathrm{CH}_{2} \mathrm{OH}$ and RSR13, that were present at $\sim 67 \%, \sim 15 \%$ and $\sim 18 \%$, respectively (Fig. S3). L-cysteine is apparently hydrolyzing the carboxylate and nitrate ester groups of DD-1 to yield RSR13 and RSR13- $\mathrm{CH}_{2} \mathrm{CH}_{2} \mathrm{OH}$, respectively, although most of the DD-1 still remained intact. In contrast, DD-3 in the presence of L-cysteine showed two main compounds (Fig. S3); corresponding to intact DD-3 ( 60\%) and RSR13 ( 40\%). Hydrolysis of the DD-3 carboxylate ester by L-cysteine appears to be more efficient than the DD-1 carboxylate ester.

Unlike L-cysteine, when DD-1 is incubated with human serum (containing non-specific esterases) for $24 \mathrm{hrs}$ at $37^{\circ} \mathrm{C}$, almost $100 \%$ of RSR13 was produced (Fig. S4). DD-3 on the other hand yielded a mixture of unreacted DD-3 ( 60\%) and RSR13 ( 40\%) (Fig. S4), the same ratio as when incubated with L-cysteine (Fig. S3). It seems that esterases are more efficient in cleaving the carboxylate ester bond of the nitrooxyalkyl prodrug than that of the diazen-1-ium-1,2-diolate prodrug. Nevertheless, there appears to be no direct correlation between cleavage of the carboxylate ester (to form RSR13) by esterases and the amount of NO released, as DD-1 which was completely hydrolyzed to RSR 13 only released at most $9 \%$ of NO, while DD-3 which resulted in $~ 40 \%$ transformation to RSR13 released $41-50 \%$ NO. This observation suggests a different mechanism(s) of denitration in the two classes of compounds.

The crystal structure of deoxyHb co-crystallized with DD-1 showed bound DD-1, RSR13, $\mathrm{NO}$, nitrate, and possibly RSR13- $\mathrm{CH}_{2} \mathrm{CH}_{2} \mathrm{OH}$ to the protein. We therefore used UPLC-MS to follow the reaction products of DD-1 when incubated with the crystallization buffer $(0.2$ M sodium acetate trihydrate, $0.1 \mathrm{M}$ sodium cacodylate trihydrate $\mathrm{pH} 6.5$ and 30\% w/v PEG 8000) containing sodium dithionite at room temperature to determine whether we could observe similar degradation products. After 2 days of incubation (where crystals normally start to appear), we identified DD-1 ( 73\%), RSR13- $\mathrm{CH}_{2} \mathrm{CH}_{2} \mathrm{OH}(\sim 18 \%)$ and RSR13 ( 9\%), and at 8 days the mixture composition changed to DD-1 ( 56\%), RSR13$\mathrm{CH}_{2} \mathrm{CH}_{2} \mathrm{OH}(\sim 38 \%)$ and RSR13 ( 6\%) (Fig. S5). Note that when sodium dithionite is removed from the reaction solution, DD-1 did not undergo hydrolysis, clearly indicating that sodium dithionite is responsible for both the carboxylate and nitrate ester hydrolyses to produce RSR13 and RSR13- $\mathrm{CH}_{2} \mathrm{CH}_{2} \mathrm{OH}$, respectively, consistent with the structural findings. The large amount of DD-1 and small amount of RSR13 in the reaction mixture also 
confirms our proposition that the observed weak effector electron density is due to Hb lowaffinity for DD-1, as well as slow reaction between $\mathrm{Hb}$ and the prodrug.

We also followed the reaction products of DD-1 and DD-3 in whole blood at both room temperature and $37^{\circ} \mathrm{C}$. At room temperature, when DD- 1 was incubated with whole blood for $16 \mathrm{hrs}$, we observed a mixture of DD-1 ( 70\%) and RSR13 ( $\sim 30)$, and for DD-3; we also observed a mixture of DD-3 ( 83\%) and RSR13 ( 17\%), respectively (Fig. S6). At $37^{\circ} \mathrm{C}$, formation of RSR13 from both DD-1 and DD-3 significantly increased from $\sim 30 \%$ to $\sim 57 \%$, and $\sim 17 \%$ to $\sim 83 \%$, respectively (Fig. S6). The result is consistent with the expected hydrolysis of the carboxylate ester of these compounds by esterases and perhaps other enzymes to form RSR13. Note that neither prodrug at room temperature or $37^{\circ} \mathrm{C}$ showed any degradation product with DMSO alone, buffer or BSA (Figs. S1 and S2).

Finally, when DD-1 or DD-3 was incubated with clarified $\mathrm{Hb}$ (similar to the condition used for OEC analysis) for $16 \mathrm{hrs}$ at room temperature, there was no apparent formation of degradation product (Fig. S7). This observation clearly suggests that the observed weak and delayed allosteric activity with clarified $\mathrm{Hb}$ is due to direct binding of the prodrugs to $\mathrm{Hb}$, and emphasize the importance of hydrolysis of the prodrug into RSR 13 to effect fast and significant allosteric activity. It is clear that the non-biological matrix, L-cysteine and sodium dithionite act on both the carboxylate and nitrate esters of DD-1 to yield RSR13 and RSR13- $\mathrm{CH}_{2} \mathrm{CH}_{2} \mathrm{OH}$; however, in the presence of the biological matrices, serum and whole blood we only observed the final reaction product RSR13. DD-2 should behave similarly as DD-1. DD-3 as expected from its chemical composition yielded only RSR13 in all matrices. Based on our results, and the previously proposed mechanism of biotransformation of NOreleasing prodrugs containing carboxylate and/or nitrate ester groups ${ }^{34,60}$ we expect the carboxylate ester bond of DD-1 and DD-2 to be hydrolyzed producing RSR13, and the hydroxyalkylnitrate group ( $\mathrm{HO}-\left(\mathrm{CH}_{2}\right) \mathrm{nONO}_{2}$; where $\mathrm{n}=2$ (DD-1) or 3 (DD-2)) and nitrite ion, the latter two compounds undergoing subsequent denitration reaction to release NO metabolites, including NO that may involve a series of enzymatic action and/or direct $3 \mathrm{e}^{-}$ reduction ${ }^{60,91-98}$. The diazen-1-ium-1,2-diolate prodrug is also expected to undergo ester hydrolysis at the carboxylate group to release RSR13 and 2-(hydroxymethoxy)-1(pyrrolidin-1-yl)diazene 1-oxide, the latter undergoing further dinitration to yield $\mathrm{NO}^{34}$.

\section{Conclusions}

RSR13 is an allosteric effector of $\mathrm{Hb}$ that decreases its affinity for $\mathrm{O}_{2}$, and as a result allows release of more $\mathrm{O}_{2}$ to tissues ${ }^{5}$. Decreased NO is a cause of several pathological conditions, and increasing its local bioavailability has also found use in several ischemic-related pathologies due to its vasodilatory property ${ }^{28-36,99}$. We have synthesized a new group of NO-releasing prodrugs possessing either nitrooxyalkyl or 1-(pyrrolidin-1-yl)diazen-1ium-1,2-diolate moiety attached to the carboxylate of RSR13. In-vitro functional/biological studies showed that the compounds effectively released NO in serum/blood and also lowered the $\mathrm{O}_{2}$ affinity of $\mathrm{Hb}$, providing a potential a dual mechanism of action that may be beneficial in the treatment of ischemic-underlying diseases. Nonetheless, the study suggests the diazen-1-ium-1,2-diolate prodrugs of RSR13 to be potentially more superior than the nitrooxyalkyl analogs, which would have to be confirmed with animal model studies. The 
crystal structure of deoxygenated $\mathrm{Hb}$ co-crystallized with DD-1 showed the ester hydrolysis products, RSR13 and NO bound to the central water cavity and a-heme iron, respectively. Another interesting structural finding was a nitrate bound at the $\beta$ His 97 , the relevance and significance of which is yet to be determined, but provides the groundwork for future investigations. Overall, the study not only provides feasibility of discovering potential therapeutic agents for the treatment of ischemic-related disease, it also provides new insight into the biotransformation of NO-releasing prodrugs, offer atomic level understanding of how the compounds may function in vivo to effect their pharmacologic activities, and contribute to our understanding of Hb-NO biochemistry.

\section{Supplementary Material}

Refer to Web version on PubMed Central for supplementary material.

\section{Acknowledgments}

We thank Dr. Umesh Desai at the Virginia Commonwealth University for the UPLC-MS analysis. The Supporting Information is available free of charge on the ACS Publications website at http://pubs.acs.org.

\section{Abbreviations}

\begin{tabular}{ll} 
Hb & hemoglobin \\
OEC & oxygen equilibrium curve \\
RBC & red blood cell \\
deoxyHb & deoxygenated hemoglobin \\
COHb & carbonmonoxy hemoglobin \\
metHb & methemoglobin \\
NO & nitric oxide \\
HbNO & nitrosylHb \\
HbSNO & S-nitrosoHb \\
pO2 & partial pressure of oxygen \\
2,3-DPG & 2,3-diphosphoglycerate \\
R-state & relaxed state \\
T-state & tense state \\
\hline
\end{tabular}

\section{References}

1. Back T, Kohno K, Hossmann KA. Cortical negative DC deflections following middle cerebral artery occlusion and $\mathrm{KCl}$-induced spreading depression: Effect on blood flow, tissue oxygenation, and electroencephalogram. J Cereb Blood Flow Metab. 1994; 14:12-19. [PubMed: 8263047] 
2. Safo MK, Ahmed MH, Ghatge MS, Boyiri T. Hemoglobin-ligand binding: Understanding hb function and allostery on atomic level. Biochim Biophys Acta. 2011; 1814:797-809. [PubMed: 21396487]

3. Poyart C, Marden MC, Kister J. Bezafibrate derivatives as potent effectors of hemoglobin. Methods Enzymol. 1994; 232:496-513. [PubMed: 8057877]

4. Liong C, Ortiz D, Ao-ieong E, Navati MS, Friedman JM, Cabrales P. Localized increase of tissue oxygen tension by magnetic targeted drug delivery. Nanotechnology. 2014; 25:265102/4484/25/26/265102. Epub 2014 Jun 12. [PubMed: 24920392]

5. Safo MK, Moure CM, Burnett JC, Joshi GS, Abraham DJ. High-resolution crystal structure of deoxy hemoglobin complexed with a potent allosteric effector. Protein Sci. 2001; 10:951-957. [PubMed: 11316875]

6. Watson JC, Doppenberg EM, Bullock MR, Zauner A, Rice MR, Abraham D, Young HF. Effects of the allosteric modification of hemoglobin on brain oxygen and infarct size in a feline model of stroke. Stroke. 1997; 28:1624-1630. [PubMed: 9259760]

7. Suh JH, Stea B, Nabid A, Kresl JJ, Fortin A, Mercier JP, Senzer N, Chang EL, Boyd AP, Cagnoni PJ, Shaw E. Phase III study of efaproxiral as an adjunct to whole-brain radiation therapy for brain metastases. J Clin Oncol. 2006; 24:106-114. [PubMed: 16314619]

8. Scott C, Suh J, Stea B, Nabid A, Hackman J. Improved survival, quality of life, and quality-adjusted survival in breast cancer patients treated with efaproxiral (efaproxyn) plus whole-brain radiation therapy for brain metastases. Am J Clin Oncol. 2007; 30:580-587. [PubMed: 18091051]

9. Wong GK, Marsden PA. Nitric oxide synthases: Regulation in disease. Nephrol Dial Transplant. 1996; 11:215-220. [PubMed: 8649643]

10. Lamas S, Perez-Sala D, Moncada S. Nitric oxide: From discovery to the clinic. Trends Pharmacol Sci. 1998; 19:436-438. [PubMed: 9850605]

11. Ignarro LJ. Nitric oxide: A unique endogenous signaling molecule in vascular biology. Biosci Rep. 1999; 19:51-71. [PubMed: 10888468]

12. De Franceschi L. Pathophisiology of sickle cell disease and new drugs for the treatment. Mediterr J Hematol Infect Dis. 2009; 1:e2009024. [PubMed: 21415994]

13. Bin JP, Doctor A, Lindner J, Hendersen EM, Le DE, Leong-Poi H, Fisher NG, Christiansen J, Kaul S. Effects of nitroglycerin on erythrocyte rheology and oxygen unloading: Novel role of Snitrosohemoglobin in relieving myocardial ischemia. Circulation. 2006; 113:2502-2508. [PubMed: 16717147]

14. Muscara MN, Wallace JL. Nitric oxide. V therapeutic potential of nitric oxide donors and inhibitors. Am J Physiol. 1999; 276:G1313-6. [PubMed: 10362633]

15. Wallis JP. Nitric oxide and blood: A review. Transfus Med. 2005; 15:1-11.

16. Liu C, Wajih N, Liu X, Basu S, Janes J, Marvel M, Keggi C, Helms CC, Lee AN, Belanger AM, Diz DI, Laurienti PJ, Caudell DL, Wang J, Gladwin MT, Kim-Shapiro DB. Mechanisms of human erythrocytic bioactivation of nitrite. J Biol Chem. 2015; 290:1281-1294. [PubMed: 25471374]

17. McKnight GM, Smith LM, Drummond RS, Duncan CW, Golden M, Benjamin N. Chemical synthesis of nitric oxide in the stomach from dietary nitrate in humans. Gut. 1997; 40:211-214. [PubMed: 9071933]

18. Benjamin N, O'Driscoll F, Dougall H, Duncan C, Smith L, Golden M, McKenzie H. Stomach NO synthesis. Nature. 1994; 368:502.

19. Lundberg JO, Weitzberg E. NO generation from nitrite and its role in vascular control. Arterioscler Thromb Vasc Biol. 2005; 25:915-922. [PubMed: 15746440]

20. Lundberg JO, Weitzberg E, Cole JA, Benjamin N. Nitrate, bacteria and human health. Nat Rev Microbiol. 2004; 2:593-602. [PubMed: 15197394]

21. Weiner DL, Brugnara C. Hydroxyurea and sickle cell disease: A chance for every patient. JAMA. 2003; 289:1692-1694. [PubMed: 12672739]

22. Huang J, Kim-Shapiro DB, King SB. Catalase-mediated nitric oxide formation from hydroxyurea. J Med Chem. 2004; 47:3495-3501. [PubMed: 15214777]

23. Rossaint R, Falke KJ, Lopez F, Slama K, Pison U, Zapol WM. Inhaled nitric oxide for the adult respiratory distress syndrome. N Engl J Med. 1993; 328:399-405. [PubMed: 8357359] 
24. Sheridan RL, Zapol WM, Ritz RH, Tompkins RG. Low-dose inhaled nitric oxide in acutely burned children with profound respiratory failure. Surgery. 1999; 126:856-862. [PubMed: 10568185]

25. Ichinose F, Roberts JD Jr, Zapol WM. Inhaled nitric oxide: A selective pulmonary vasodilator: Current uses and therapeutic potential. Circulation. 2004; 109:3106-3111. [PubMed: 15226227]

26. Cabrales P, Han G, Nacharaju P, Friedman AJ, Friedman JM. Reversal of hemoglobin-induced vasoconstriction with sustained release of nitric oxide. Am J Physiol Heart Circ Physiol. 2011; 300:H49-56. [PubMed: 21057038]

27. Nachuraju P, Friedman AJ, Friedman JM, Cabrales P. Exogenous nitric oxide prevents cardiovascular collapse during hemorrhagic shock. Resuscitation. 2011; 82:607-613. [PubMed: 21342744]

28. Ignarro LJ, Lippton H, Edwards JC, Baricos WH, Hyman AL, Kadowitz PJ, Gruetter CA. Mechanism of vascular smooth muscle relaxation by organic nitrates, nitrites, nitroprusside and nitric oxide: Evidence for the involvement of S-nitrosothiols as active intermediates. J Pharmacol Exp Ther. 1981; 218:739-749. [PubMed: 6115052]

29. Bates JN, Harrison DG, Myers PR, Minor RL. EDRF: Nitrosylated compound or authentic nitric oxide. Basic Res Cardiol. 1991; 86(Suppl 2):17-26. [PubMed: 1953608]

30. Stamler J, Jaraki O, Osborne J, Simon D, Keaney J, Vita J, Loscalzo J. S-nitroso-albumin is the predominant bioactive form of nitric-oxide in human plasma. Circulation. 1992; 86:757.

31. Stamler JS, Jaraki O, Osborne J, Simon DI, Keaney J, Vita J, Singel D, Valeri CR, Loscalzo J. Nitric oxide circulates in mammalian plasma primarily as an S-nitroso adduct of serum albumin. Proc Natl Acad Sci U S A. 1992; 89:7674-7677. [PubMed: 1502182]

32. Napoli C, Ignarro LJ. Nitric oxide-releasing drugs. Annu Rev Pharmacol Toxicol. 2003; 43:97123. [PubMed: 12540742]

33. Kaur J, Bhardwaj A, Huang Z, Narang D, Chen TY, Plane F, Knaus EE. Synthesis and biological investigations of nitric oxide releasing nateglinide and meglitinide type II antidiabetic prodrugs: In-vivo antihyperglycemic activities and blood pressure lowering studies. J Med Chem. 2012; 55:7883-7891. [PubMed: 22916833]

34. Velazquez C, Praveen Rao PN, Knaus EE. Novel nonsteroidal antiinflammatory drugs possessing a nitric oxide donor diazen-1-ium-1,2-diolate moiety: Design, synthesis, biological evaluation, and nitric oxide release studies. J Med Chem. 2005; 48:4061-4067. [PubMed: 15943479]

35. Flaherty JT. Role of nitrates in acute myocardial infarction. Am J Cardiol. 1992; 70:73B-81B. [PubMed: 1615874]

36. Gruetter DY, Gruetter CA, Barry BK, Baricos WH, Hyman AL, Kadowitz PJ, Ignarro LJ. Activation of coronary arterial guanylate cyclase by nitric oxide, nitroprusside, and nitrosoguanidine--inhibition by calcium, lanthanum, and other cations, enhancement by thiols. Biochem Pharmacol. 1980; 29:2943-2950. [PubMed: 6109533]

37. Cosby K, Partovi KS, Crawford JH, Patel RP, Reiter CD, Martyr S, Yang BK, Waclawiw MA, Zalos G, Xu X, Huang KT, Shields H, Kim-Shapiro DB, Schechter AN, Cannon RO 3rd, Gladwin MT. Nitrite reduction to nitric oxide by deoxyhemoglobin vasodilates the human circulation. Nat Med. 2003; 9:1498-1505. [PubMed: 14595407]

38. Gladwin MT, Schechter AN, Kim-Shapiro DB, Patel RP, Hogg N, Shiva S, Cannon RO 3rd, Kelm M, Wink DA, Espey MG, Oldfield EH, Pluta RM, Freeman BA, Lancaster JR Jr, Feelisch M, Lundberg JO. The emerging biology of the nitrite anion. Nat Chem Biol. 2005; 1:308-314. [PubMed: 16408064]

39. Curtis E, Hsu LL, Noguchi AC, Geary L, Shiva S. Oxygen regulates tissue nitrite metabolism. Antioxid Redox Signal. 2012; 17:951-961. [PubMed: 22098300]

40. Gladwin MT, Kim-Shapiro DB. Vascular biology: Nitric oxide caught in traffic. Nature. 2012; 491:344-345. [PubMed: 23123855]

41. Gladwin MT, Shelhamer JH, Schechter AN, Pease-Fye ME, Waclawiw MA, Panza JA, Ognibene FP, Cannon RO 3rd. Role of circulating nitrite and S-nitrosohemoglobin in the regulation of regional blood flow in humans. Proc Natl Acad Sci U S A. 2000; 97:11482-11487. [PubMed: 11027349] 
42. Modin A, Björne H, Herulf M, Alving K, Weitzberg E, Lundberg JON. Nitrite-derived nitric oxide: A possible mediator of "acidic metabolic" vasodilation. Acta Physiol Scand. 2001; 171:9-16. [PubMed: 11350258]

43. Li H, Samouilov A, Liu X, Zweier JL. Characterization of the magnitude and kinetics of xanthine oxidase-catalyzed nitrite reduction: Evaluation of its role in nitric oxide generation in anoxic tissues. Journal of Biological Chemistry. 2001; 276:24482-24489. [PubMed: 11312267]

44. Dejam A, Hunter CJ, Pelletier MM, Hsu LL, Machado RF, Shiva S, Power GG, Kelm M, Gladwin MT, Schechter AN. Erythrocytes are the major intravascular storage sites of nitrite in human blood. Blood. 2005; 106:734-739. [PubMed: 15774613]

45. Kelm, M., Yoshida, K. Metabolic Fate of Nitric Oxide and Related N-Oxides. 1. Feelisch, M., Stamler, JS., editors. Wiley; London: 1996. p. 47-58.

46. Wennmalm A, Benthin G, Petersson AS. Dependence of the metabolism of nitric oxide (NO) in healthy human whole blood on the oxygenation of its red cell haemoglobin. Br J Pharmacol. 1992; 106:507-508. [PubMed: 1504736]

47. Pietraforte D, Mallozzi C, Scorza G, Minetti M. Role of thiols in the targeting of S-nitroso thiols to red blood cells. Biochemistry. 1995; 34:7177-7185. [PubMed: 7766628]

48. Chan NL, Kavanaugh JS, Rogers PH, Arnone A. Crystallographic analysis of the interaction of nitric oxide with quaternary-T human hemoglobin. Biochemistry. 2004; 43:118-132. [PubMed: 14705937]

49. Yi J, Soares AS, Richter-Addo GB. Crystallographic characterization of the nitric oxide derivative of R-state human hemoglobin. Nitric Oxide. 2014; 39:46-50. [PubMed: 24769418]

50. Jia L, Bonaventura C, Bonaventura J, Stamler JS. S-nitrosohaemoglobin: A dynamic activity of blood involved in vascular control. Nature. 1996; 380:221-226. [PubMed: 8637569]

51. Stamler JS, Jia L, Eu JP, McMahon TJ, Demchenko IT, Bonaventura J, Gernert K, Piantadosi CA. Blood flow regulation by S-nitrosohemoglobin in the physiological oxygen gradient. Science. 1997; 276:2034-2037. [PubMed: 9197264]

52. Patel RP, Hogg N, Spencer NY, Kalyanaraman B, Matalon S, Darley-Usmar VM. Biochemical characterization of human S-nitrosohemoglobin. effects on oxygen binding and transnitrosation. $\mathrm{J}$ Biol Chem. 1999; 274:15487-15492. [PubMed: 10336440]

53. Chan NL, Rogers PH, Arnone A. Crystal structure of the S-nitroso form of liganded human hemoglobin. Biochemistry. 1998; 37:16459-16464. [PubMed: 9843411]

54. Safo MK, Abraham DJ. X-ray crystallography of hemoglobins. Methods Mol Med. 2003; 82:1-19. [PubMed: 12669634]

55. Abdulmalik O, Safo MK, Chen Q, Yang J, Brugnara C, Ohene-Frempong K, Abraham DJ, Asakura T. 5-hydroxymethyl-2-furfural modifies intracellular sickle haemoglobin and inhibits sickling of red blood cells. Br J Haematol. 2005; 128:552-561. [PubMed: 15686467]

56. Safo MK, Abdulmalik O, Danso-Danquah R, Burnett JC, Nokuri S, Joshi GS, Musayev FN, Asakura T, Abraham DJ. Structural basis for the potent antisickling effect of a novel class of fivemembered heterocyclic aldehydic compounds. J Med Chem. 2004; 47:4665-4676. [PubMed: 15341482]

57. Brunger AT, Adams PD, Clore GM, DeLano WL, Gros P, Grosse-Kunstleve RW, Jiang JS, Kuszewski J, Nilges M, Pannu NS, Read RJ, Rice LM, Simonson T, Warren GL. Crystallography \& NMR system: A new software suite for macromolecular structure determination. Acta Crystallogr D Biol Crystallogr. 1998; 54:905-921. [PubMed: 9757107]

58. Emsley P, Cowtan K. Coot: Model-building tools for molecular graphics. Acta Crystallogr D Biol Crystallogr. 2004; 60:2126-2132. [PubMed: 15572765]

59. Tang X, Xian M, Trikha M, Honn KV, Wang PG. Synthesis of peptide-diazeniumdiolate conjugates: Towards enzyme activated antitumor agents. Tetrahedron Lett. 2001; 42:2625-2629.

60. Thatcher GR, Nicolescu AC, Bennett BM, Toader V. Nitrates and NO release: Contemporary aspects in biological and medicinal chemistry. Free Radic Biol Med. 2004; 37:1122-1143. [PubMed: 15451053]

61. Keefer LK. Progress toward clinical application of the nitric oxide-releasing diazeniumdiolates. Annu Rev Pharmacol Toxicol. 2003; 43:585-607. [PubMed: 12415121] 
62. Csont T, Ferdinandy P. Cardioprotective effects of glyceryl trinitrate: Beyond vascular nitrate tolerance. Pharmacol Ther. 2005; 105:57-68. [PubMed: 15626455]

63. Wang EQ, Balthasar JP, Fung HL. Pharmacodynamics of in vivo nitroglycerin tolerance in normal conscious rats: Effects of dose and dosing protocol. Pharm Res. 2004; 21:114-120. [PubMed: 14984265]

64. Park SY, Yokoyama T, Shibayama N, Shiro Y, Tame JR. 1.25 A resolution crystal structures of human haemoglobin in the oxy, deoxy and carbonmonoxy forms. J Mol Biol. 2006; 360:690-701. [PubMed: 16765986]

65. Phelps Grella M, Danso-Danquah R, Safo MK, Joshi GS, Kister J, Marden M, Hoffman SJ, Abraham DJ. Synthesis and structure-activity relationships of chiral allosteric modifiers of hemoglobin. J Med Chem. 2000; 43:4726-4737. [PubMed: 11123981]

66. Youssef AM, Safo MK, Danso-Danquah R, Joshi GS, Kister J, Marden MC, Abraham DJ. Synthesis and X-ray studies of chiral allosteric modifiers of hemoglobin. J Med Chem. 2002; 45:1184-1195. [PubMed: 11881987]

67. Cheng, L., Richter-Addo, GB. Binding and Activation of Nitric Oxide by Metalloporphyrins and Heme. In: Guilard, R.Smith, K., Kadish, KM., editors. The Porphyrin Handbook. Vol. 4. Academic Press; New York: 2000. p. 219-291.

68. McMahon TJ, Exton Stone A, Bonaventura J, Singel DJ, Solomon Stamler J. Functional coupling of oxygen binding and vasoactivity in S-nitrosohemoglobin. J Biol Chem. 2000; 275:1673816745. [PubMed: 10747928]

69. Cassoly R, Gibson Q. Conformation, co-operativity and ligand binding in human hemoglobin. J Mol Biol. 1975; 91:301-313. [PubMed: 171411]

70. Kim-Shapiro DB. Hemoglobin-nitric oxide cooperativity: Is NO the third respiratory ligand? Free Radic Biol Med. 2004; 36:402-412. [PubMed: 14975443]

71. Paoli M, Dodson G, Liddington RC, Wilkinson AJ. Tension in haemoglobin revealed by fe-his(F8) bond rupture in the fully liganded T-state. J Mol Biol. 1997; 271:161-167. [PubMed: 9268649]

72. Perutz MF. Stereochemical mechanism of cooperative effects in haemoglobin. Biochimie. 1972; 54:587-588. [PubMed: 4654154]

73. Perutz MF. Nature of haem-haem interaction. Nature. 1972; 237:495-499. [PubMed: 12635193]

74. Perutz MF, Wilkinson AJ, Paoli M, Dodson GG. The stereochemical mechanism of the cooperative effects in hemoglobin revisited. Annu Rev Biophys Biomol Struct. 1998; 27:1-34. [PubMed: 9646860]

75. Petruk AA, Vergara A, Estrin D, Merlino A. Molecular basis of the NO trans influence in quaternary T-state human hemoglobin: A computational study. FEBS Lett. 2013; 587:2393-2398. [PubMed: 23770098]

76. Perutz MF, TenEyck LF. Stereochemistry of cooperative effects in hemoglobin. Cold Spring Harb Symp Quant Biol. 1972; 36:295-310. [PubMed: 4508142]

77. Maxwell JC, Caughey WS. An infrared study of NO bonding to heme B and hemoglobin A. evidence for inositol hexaphosphate induced cleavage of proximal histidine to iron bonds. Biochemistry. 1976; 15:388-396. [PubMed: 1247525]

78. Moore EG, Gibson QH. Cooperativity in the dissociation of nitric oxide from hemoglobin. J Biol Chem. 1976; 251:2788-2794. [PubMed: 1262343]

79. Azizi F, Kielbasa JE, Adeyiga AM, Maree RD, Frazier M, Yakubu M, Shields H, King SB, KimShapiro DB. Rates of nitric oxide dissociation from hemoglobin. Free Radic Biol Med. 2005; 39:145-151. [PubMed: 15964506]

80. Angelo M, Hausladen A, Singel DJ, Stamler JS. Interactions of NO with hemoglobin: From microbes to man. Methods Enzymol. 2008; 436:131-168. [PubMed: 18237631]

81. Yonetani T, Tsuneshige A, Zhou Y, Chen X. Electron paramagnetic resonance and oxygen binding studies of alpha-nitrosyl hemoglobin. A novel oxygen carrier having no-assisted allosteric functions. J Biol Chem. 1998; 273:20323-20333. [PubMed: 9685383]

82. Duranski MR, Greer JJ, Dejam A, Jaganmohan S, Hogg N, Langston W, Patel RP, Yet SF, Wang X, Kevil CG, Gladwin MT, Lefer DJ. Cytoprotective effects of nitrite during in vivo ischemiareperfusion of the heart and liver. J Clin Invest. 2005; 115:1232-1240. [PubMed: 15841216] 
83. Huang Z, Shiva S, Kim-Shapiro DB, Patel RP, Ringwood LA, Irby CE, Huang KT, Ho C, Hogg N, Schechter AN, Gladwin MT. Enzymatic function of hemoglobin as a nitrite reductase that produces NO under allosteric control. J Clin Invest. 2005; 115:2099-2107. [PubMed: 16041407]

84. Perutz MF, Pulsinelli PD, Ranney HM. Structure and subunit interaction of haemoglobin M milwaukee. Nat New Biol. 1972; 237:259-263. [PubMed: 4338724]

85. Perutz MF. Mechanisms of cooperativity and allosteric regulation in proteins. Q Rev Biophys. 1989; 22:139-237. [PubMed: 2675171]

86. Safo, M., Ward, KR. Google Patents. 2013. Use of hemoglobin effectors to increase the bioavailability of therapeutic gases.

87. Hobbs AJ, Gladwin MT, Patel RP, Williams DL, Butler AR. Haemoglobin: NO transporter, NO inactivator or NOne of the above? Trends Pharmacol Sci. 2002; 23:406-411. [PubMed: 12237152]

88. Schopfer FJ, Baker PR, Giles G, Chumley P, Batthyany C, Crawford J, Patel RP, Hogg N, Branchaud BP, Lancaster JR Jr, Freeman BA. Fatty acid transduction of nitric oxide signaling. nitrolinoleic acid is a hydrophobically stabilized nitric oxide donor. J Biol Chem. 2005; 280:19289-19297. [PubMed: 15764811]

89. Baker PR, Schopfer FJ, Sweeney S, Freeman BA. Red cell membrane and plasma linoleic acid nitration products: Synthesis, clinical identification, and quantitation. Proc Natl Acad Sci U S A. 2004; 101:11577-11582. [PubMed: 15273286]

90. Lim DG, Sweeney S, Bloodsworth A, White CR, Chumley PH, Krishna NR, Schopfer F, O'Donnell VB, Eiserich JP, Freeman BA. Nitrolinoleate, a nitric oxide-derived mediator of cell function: Synthesis, characterization, and vasomotor activity. Proc Natl Acad Sci U S A. 2002; 99:15941-15946. [PubMed: 12444258]

91. Gruetter CA, Barry BK, McNamara DB, Kadowitz PJ, Ignarro LJ. Coronary arterial relaxation and guanylate cyclase activation by cigarette smoke, N'-nitrosonornicotine and nitric oxide. J Pharmacol Exp Ther. 1980; 214:9-15. [PubMed: 6104719]

92. McGuire JJ, Anderson DJ, McDonald BJ, Narayanasami R, Bennett BM. Inhibition of NADPHcytochrome $\mathrm{P} 450$ reductase and glyceryl trinitrate biotransformation by diphenyleneiodonium sulfate. Biochem Pharmacol. 1998; 56:881-893. [PubMed: 9774150]

93. Sampson JB, Ye Y, Rosen H, Beckman JS. Myeloperoxidase and horseradish peroxidase catalyze tyrosine nitration in proteins from nitrite and hydrogen peroxide. Arch Biochem Biophys. 1998; 356:207-213. [PubMed: 9705211]

94. van der Vliet A, Eiserich JP, Halliwell B, Cross CE. Formation of reactive nitrogen species during peroxidase-catalyzed oxidation of nitrite. A potential additional mechanism of nitric oxidedependent toxicity. J Biol Chem. 1997; 272:7617-7625. [PubMed: 9065416]

95. Gladwin MT, Crawford JH, Patel RP. The biochemistry of nitric oxide, nitrite, and hemoglobin: Role in blood flow regulation. Free Radic Biol Med. 2004; 36:707-717. [PubMed: 14990351]

96. Ignarro LJ, Barry BK, Gruetter DY, Edwards JC, Ohlstein EH, Gruetter CA, Baricos WH. Guanylate cyclase activation of nitroprusside and nitrosoguanidine is related to formation of Snitrosothiol intermediates. Biochem Biophys Res Commun. 1980; 94:93-100. [PubMed: 6104490]

97. Ignarro LJ, Gruetter CA. Requirement of thiols for activation of coronary arterial guanylate cyclase by glyceryl trinitrate and sodium nitrite: Possible involvement of S-nitrosothiols. Biochim Biophys Acta. 1980; 631:221-231. [PubMed: 6105889]

98. Ignarro LJ, Edwards JC, Gruetter DY, Barry BK, Gruetter CA. Possible involvement of Snitrosothiols in the activation of guanylate cyclase by nitroso compounds. FEBS Lett. 1980; 110:275-278. [PubMed: 6102928]

99. Fox-Robichaud A, Payne D, Hasan SU, Ostrovsky L, Fairhead T, Reinhardt P, Kubes P. Inhaled $\mathrm{NO}$ as a viable antiadhesive therapy for ischemia/reperfusion injury of distal microvascular beds. $\mathbf{J}$ Clin Invest. 1998; 101:2497-2505. [PubMed: 9616221] 

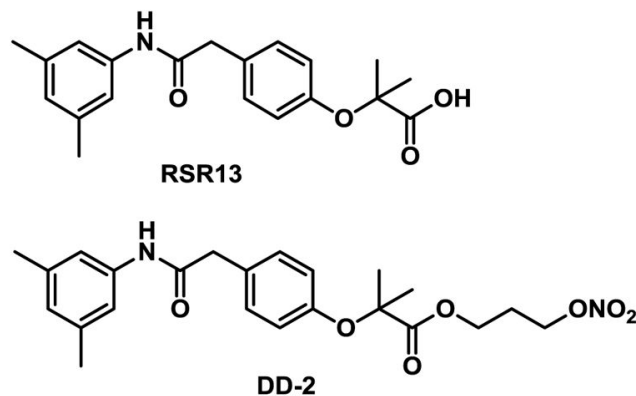
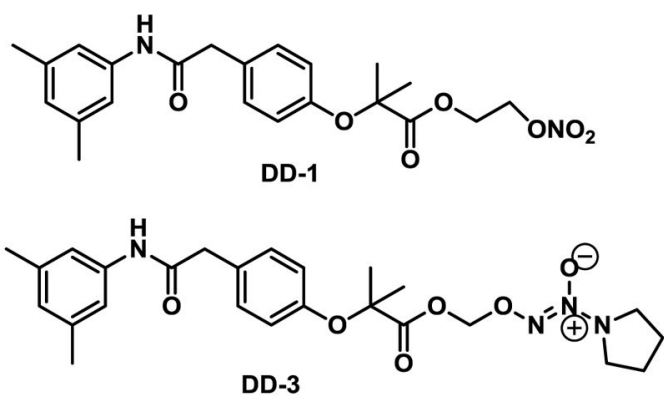

Figure 1.

Structures of RSR13 and its NO-releasing derivatives 

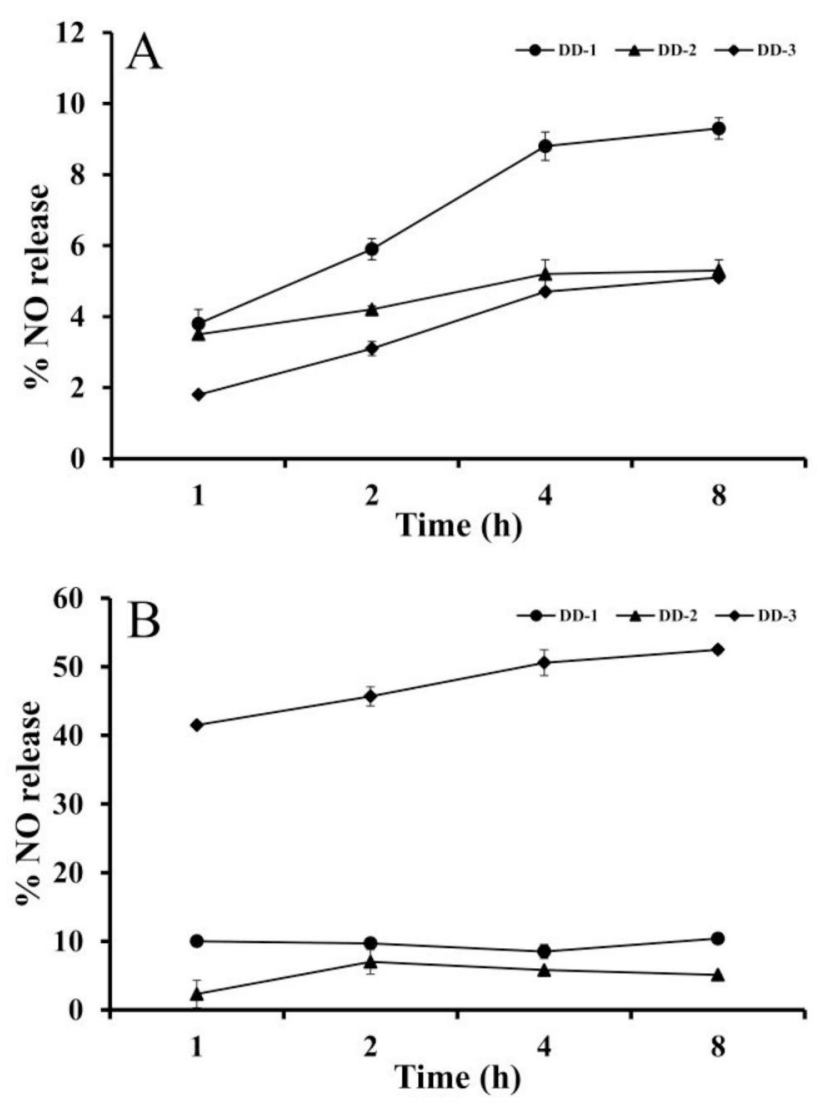

Figure 2.

$\%$ NO release by DD-1 (circle), DD-2 (triangle), and DD-3 (rhombus). (A) L-cysteine. (B) Serum 

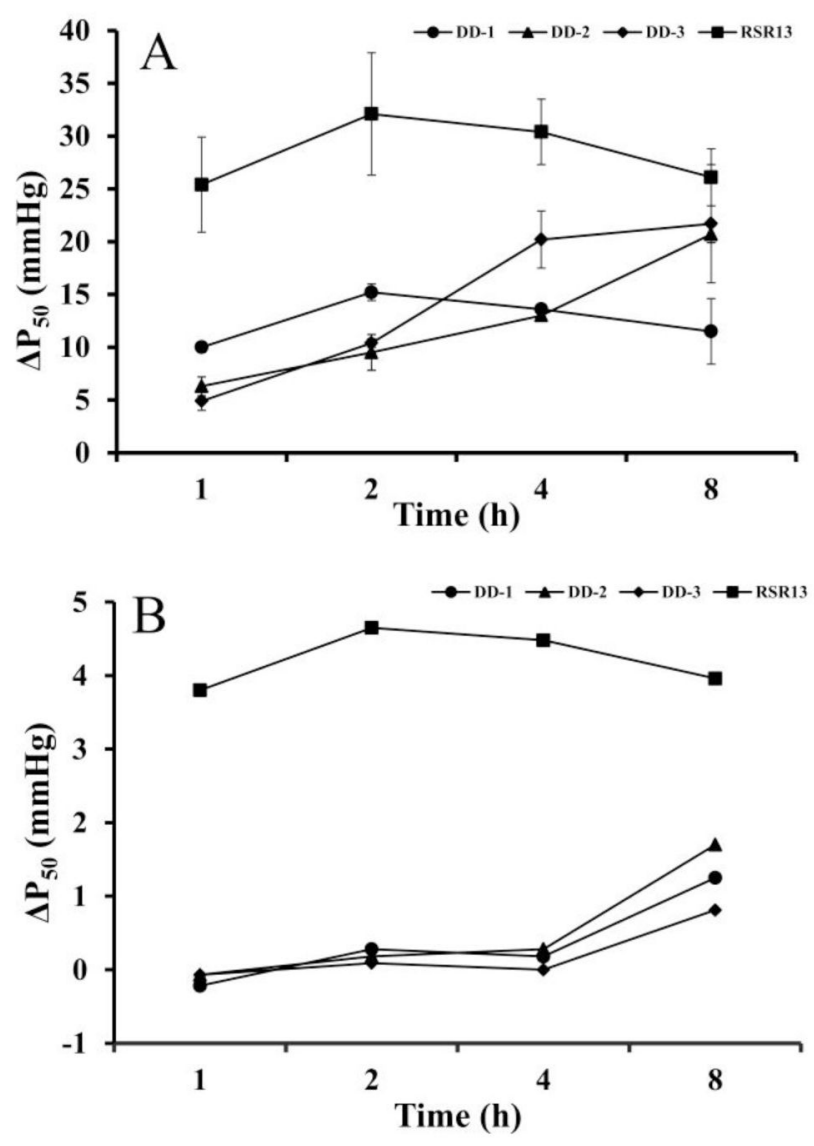

Figure 3.

Decrease $\mathrm{Hb} \mathrm{O}_{2}$-affinity (increase $\mathrm{P}_{50}$ ) by RSR13 (square), DD-1 (circle), DD-2 (triangle), and DD-3 (rhombus). (A) Whole blood (30\% HCT). (B) Clarified Hb (2mM) 


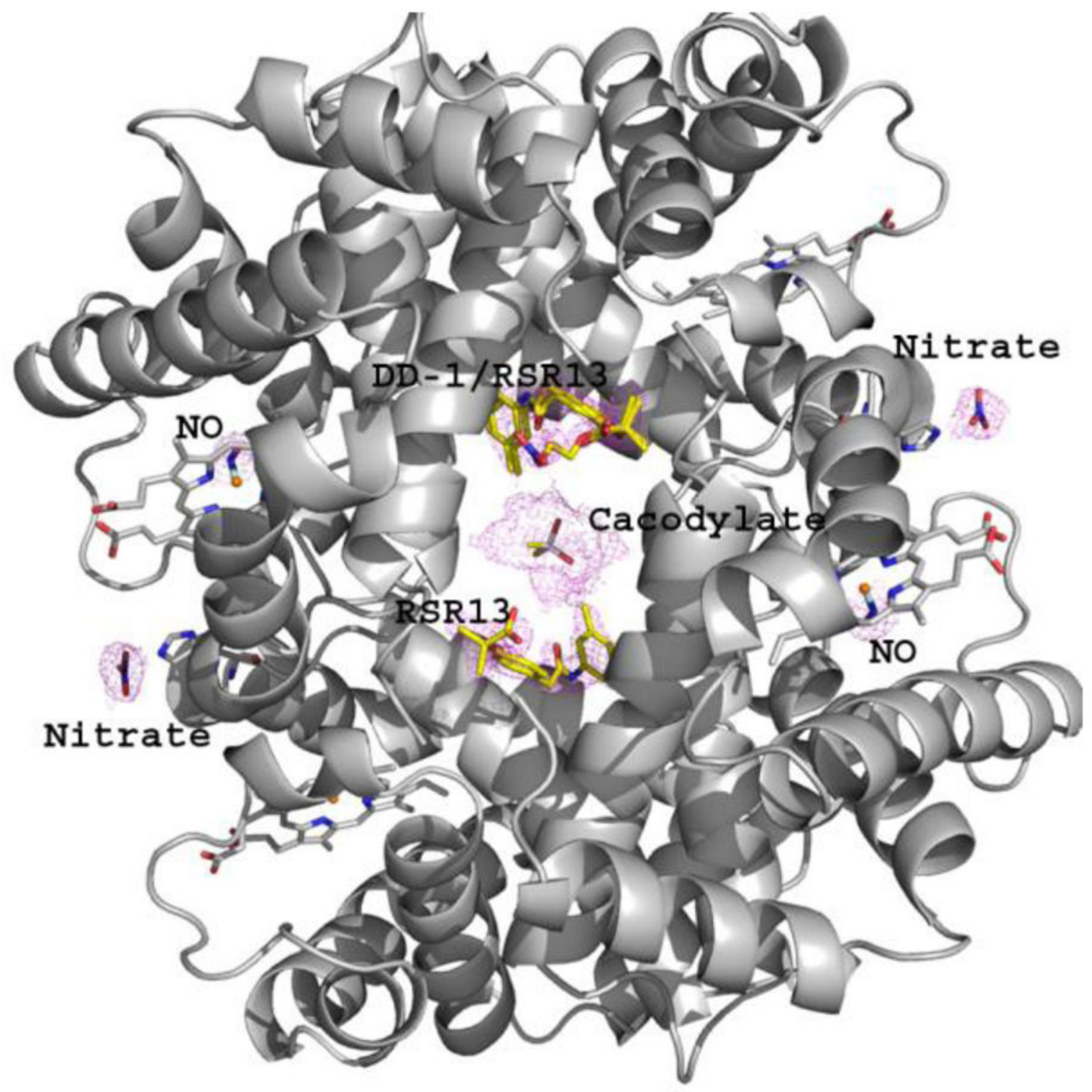

Figure 4.

Bis-ligated T-state $\mathrm{HbNO}$ structure (ribbon) showing the final $2 \mathrm{Fo}-\mathrm{Fc}$ electron electron density map (contoured at $1.0 \sigma$ ) of the bound DD-1 (yellow stick) and its hydrolysis products, RSR13 (yellow stick), NO (blue stick), and nitrate (blue stick), as well as cacodylate (yellow stick) from the precipitant. 


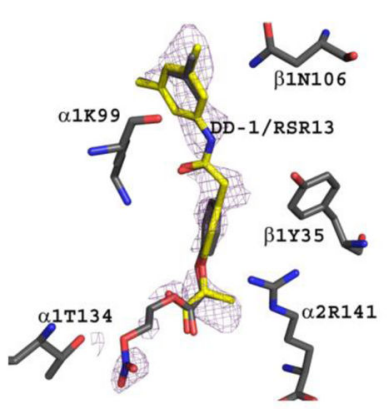

A

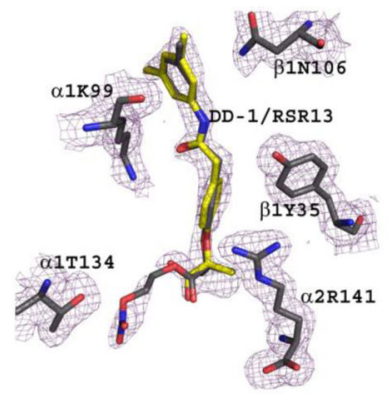

B

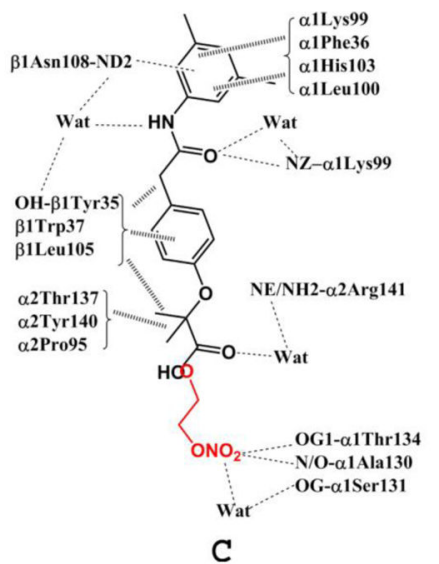

C

Figure 5.

DD-1/RSR13 interactions at the central water cavity ( 1 1a2 $\beta 1$ binding site) of bis-ligated Tstate HbNO. Note that RSR13 (yellow) and DD-1 (grey) occupy the same site of the a 1a2 21 binding site and each was refined with $40 \%$ occupancy. (A) Difference electron density (Fo-Fc) map of bound DD-1 and RSR13 (before DD-1/RSR13 were built into the model), contoured at 2.5 $\sigma$. (B) Final 2Fo-Fc map of bound DD-1 and RSR13, contoured at $1.0 \sigma$. The two maps are superimposed with the final refined DD-1/RSR13 model. For clarity, not all interacting residues are shown. (C) Schematic representation of interactions between DD-1/RSR13 and the protein. 

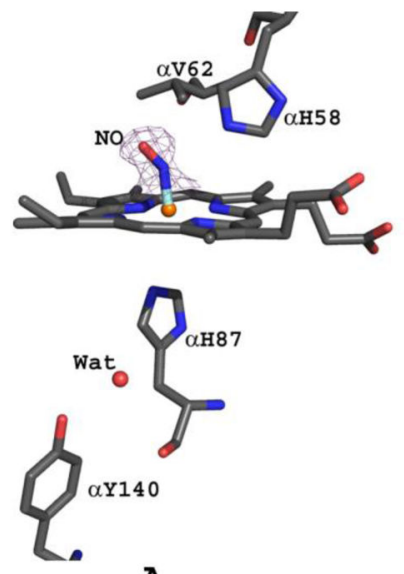

A
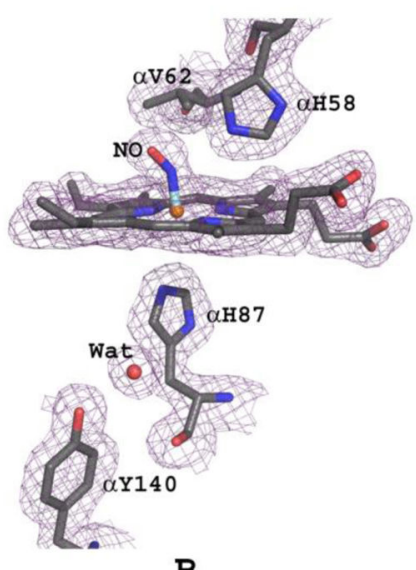

B

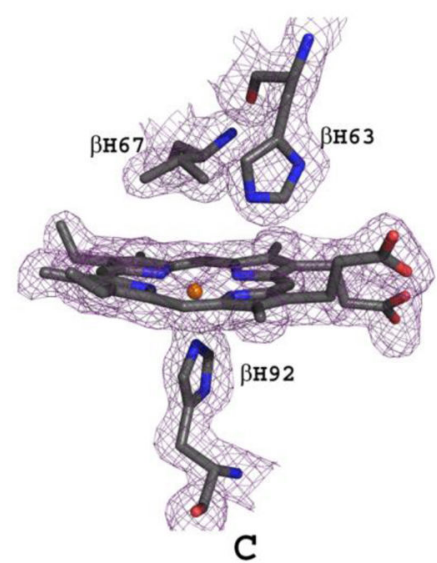

C

\section{Figure 6.}

The heme environment of bis-ligated T-state HbNO. (A) Difference electron density (Fo-Fc) map of bound NO (before NO was built into the model) at the distal side of a1-heme, contoured at 3.5 $\mathrm{\sigma}$. Similar density is observed at the a2-heme. (B) Final 2Fo-Fc map of

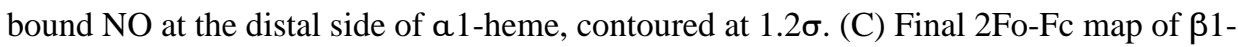
heme, contoured at $1.2 \sigma$. Similar density observed at the $\beta 2$-heme. The maps are superimposed with the final refined model. 

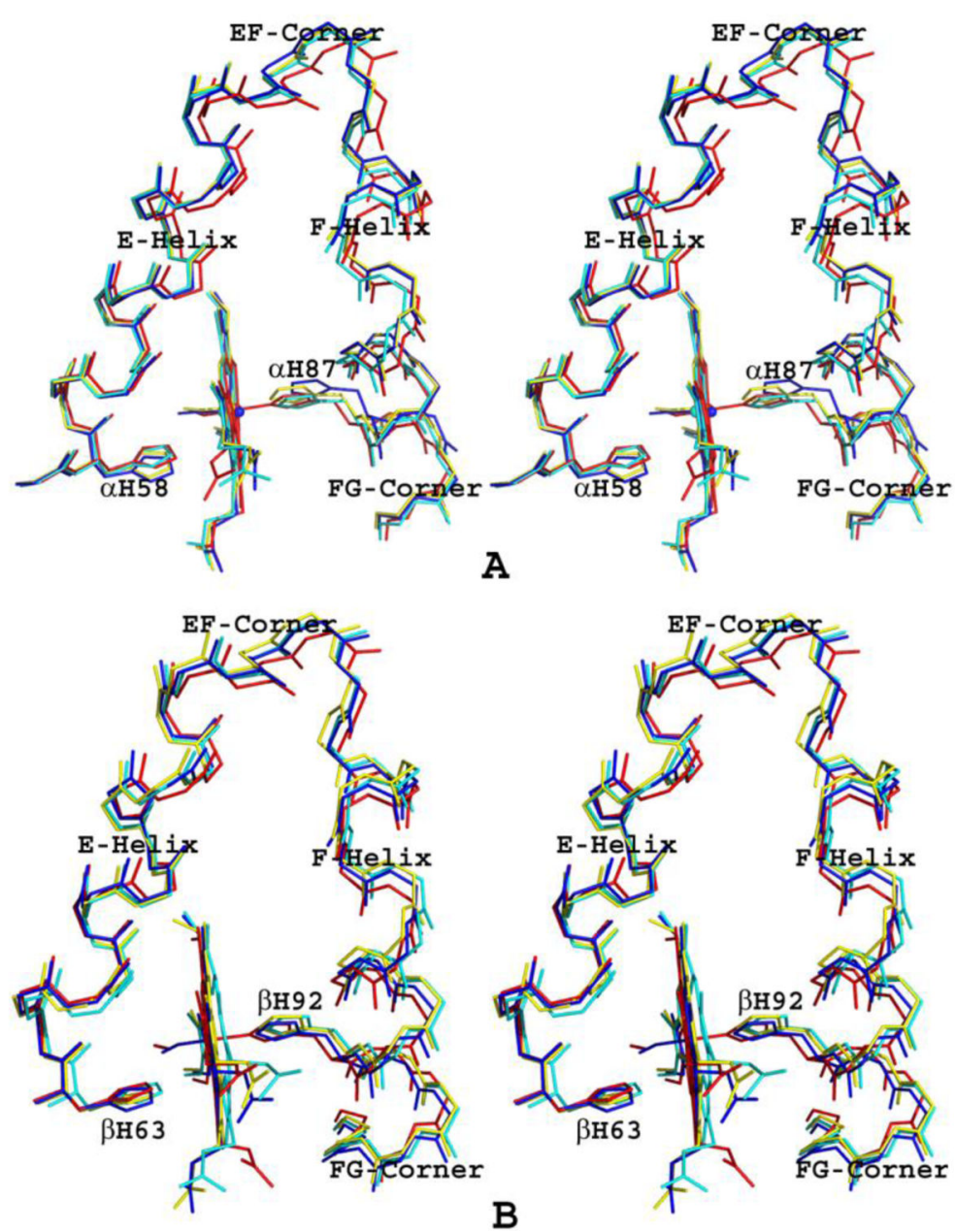

Figure 7.

Stereo diagram of superposed heme environments of bis-ligated T-state HbNO (yellow), tetra-ligated T-state $\mathrm{HbNO}$ (blue), tetra-ligated R-state $\mathrm{HbNO}$ (red), and native T-state $\mathrm{Hb}$ (cyan). (A) a1-heme environment. (B) $\beta 1$-heme environment. 


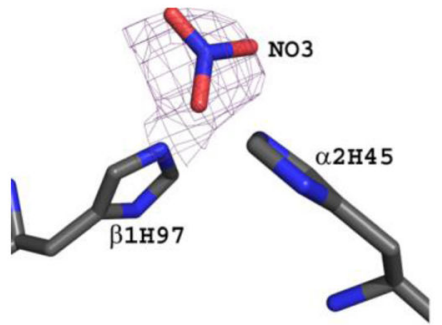

A
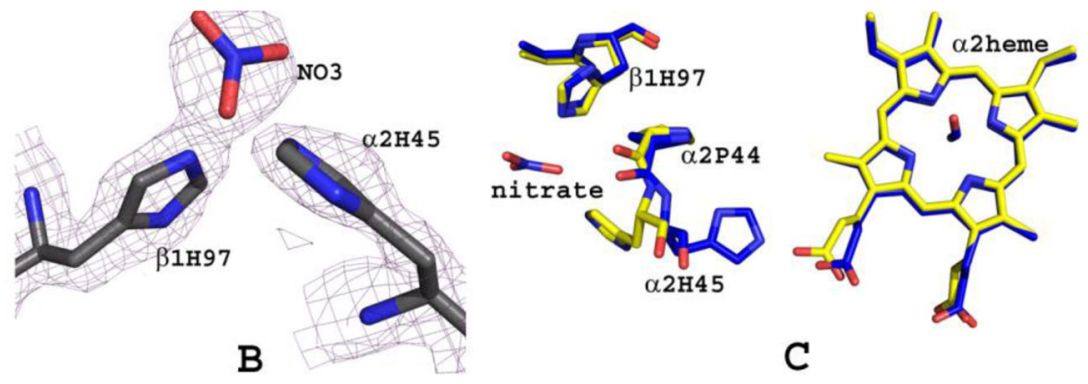

Figure 8.

Nitrate binding at $\beta$ His 97 of bis-ligated T-state HbNO. (A) Difference electron density (Fo-

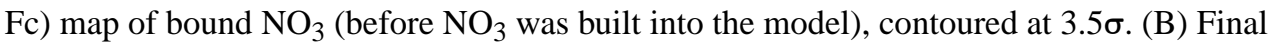
$2 \mathrm{Fo}-\mathrm{Fc}$ map of bound $\mathrm{NO}_{3}$ (before $\mathrm{NO}_{3}$ was built into the model), contoured at $1.2 \sigma$. The maps were superimposed with the final refined model. (C) Comparison of the $\mathrm{NO}_{3}$ binding site of bis-ligated T-state $\mathrm{HbNO}$ (yellow) and native T-state deoxyHb (blue). 


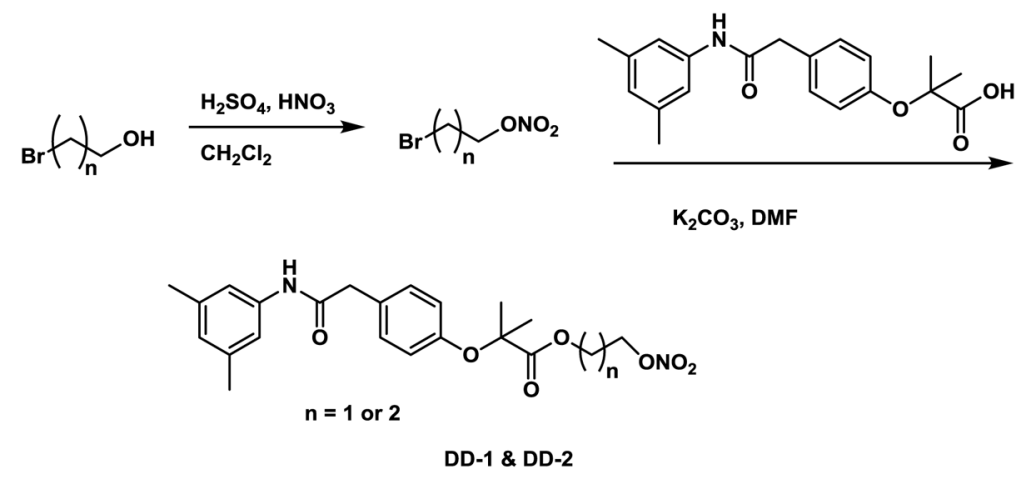

Scheme 1.

Synthetic scheme for compounds DD-1 and DD-2 
<smiles>Cc1cc(C)cc(NC(=O)Cc2ccc(OC(C)(C)C(=O)O)cc2)c1</smiles><smiles>Cc1cc(C)cc(NC(=O)Cc2ccc(OC(C)(C)C(=O)OCON=[N+]([O-])N3CCCC3)cc2)c1</smiles>

Scheme 2.

Synthetic scheme for compound DD-3 


\section{롤}

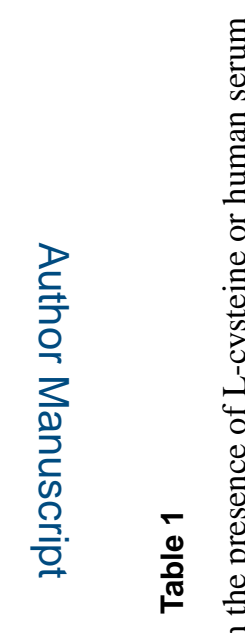

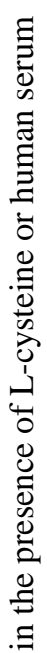

กิ่

要

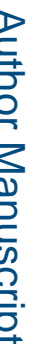

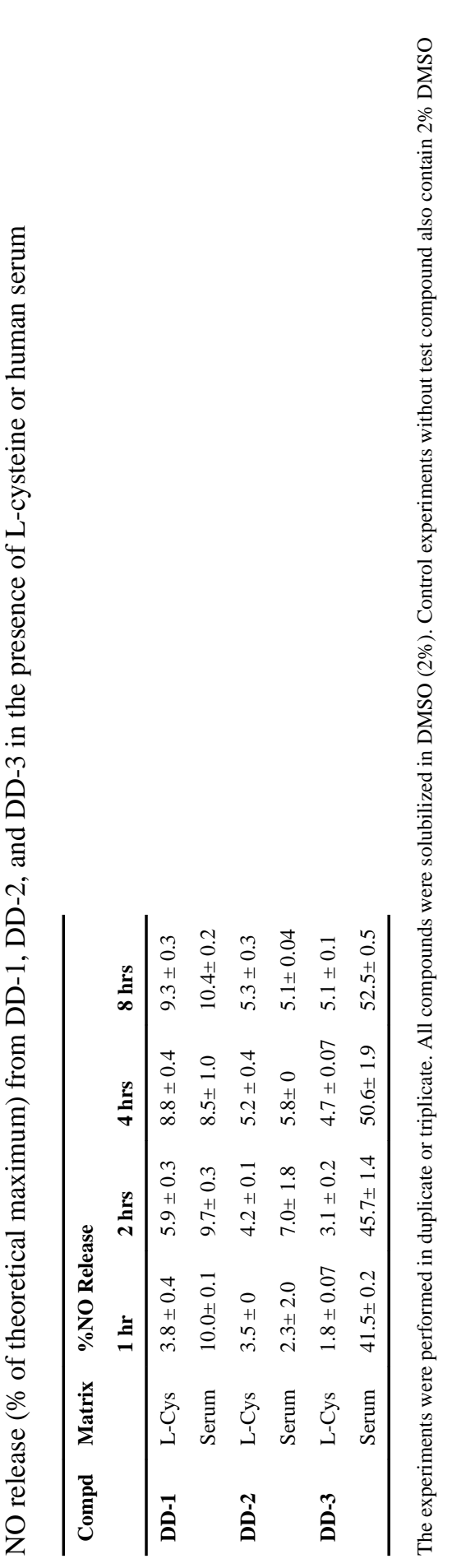

Biochemistry. Author manuscript; available in PMC 2017 June 01. 


\section{Table 2}

Effects of compounds on $\mathrm{Hb}$ oxygen affinity with normal whole blood ( $30 \%$ hematocrit).

\begin{tabular}{lllll}
\hline Compound & \multicolumn{4}{l}{$\Delta \mathbf{P}_{\mathbf{5 0}}(\mathbf{m m H g})$} \\
& $\mathbf{1 h}$ & $\mathbf{2 h}$ & $\mathbf{4 h}$ & $\mathbf{8 h}$ \\
\hline RSR13 & $25.4 \pm 4.5$ & $32.1 \pm 5.8$ & $30.4 \pm 3.1$ & $26.1 \pm 2.7$ \\
DD-1 & $10.0 \pm 0.5$ & $15.2 \pm 0.8$ & $13.6 \pm 0.5$ & $11.5 \pm 3.1$ \\
DD-2 & $6.3 \pm 0.9$ & $9.5 \pm 1.7$ & $13.0 \pm 0.4$ & $20.7 \pm 0.8$ \\
DD-3 & $4.9 \pm 0.9$ & $10.4 \pm 0.4$ & $20.2 \pm 2.7$ & $21.7 \pm 5.6$ \\
\hline
\end{tabular}

The experiments performed in duplicate or triplicate. $\Delta \mathrm{P}_{50}=\left(\mathrm{P}_{50}\right.$ control $-\mathrm{P}_{50}$ sample). All compounds were solubilized in DMSO (2\%). Control experiments without test compound also contain $2 \%$ DMSO 
Table 3

Effects of compounds on $\mathrm{Hb}$ oxygen affinity with clarified $\mathrm{Hb}(2 \mathrm{mM})$.

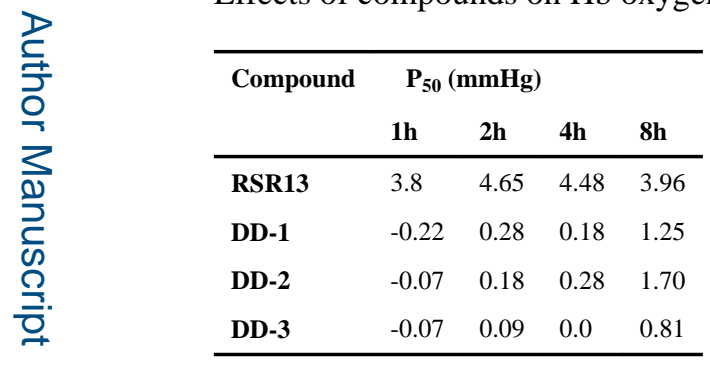

$\Delta \mathrm{P}_{50}=\left(\mathrm{P}_{50}\right.$ control $-\mathrm{P} 50$ sample $)$. All compounds were solubilized in DMSO (2\%). Control experiments without test compound also contain $2 \%$ DMSO 


\section{Table 4}

Crystallographic data and refinement statistics for bis-ligated T-state HbNO Values in parentheses refer to the outermost resolution bin.

\begin{tabular}{|c|c|}
\hline Parameters & DD-1 \\
\hline \multicolumn{2}{|l|}{ Data-collection Statistics: } \\
\hline Space group & $\mathrm{P} 22_{1} 2_{1}$ \\
\hline Unit-cell parameters $(\AA)$ & 95.8898 .4265 .4490 .0090 .0090 .00 \\
\hline Molecules in asymmetric unit & 1 \\
\hline Resolution $(\AA)$ & $29.54-1.85(1.92-1.85)$ \\
\hline No. of measurements & $291228(19980)$ \\
\hline Unique reflections $(\mathrm{I} / \sigma(\mathrm{I}))$ & $52662(4994)$ \\
\hline Avg redundancy & $5.53(4.00)$ \\
\hline Completeness (\%) & $98.2(94.3)$ \\
\hline Av. Redundancy & $5.53(4.0)$ \\
\hline $\mathrm{R}_{\text {merge }}(\%)$ & $8.4(31.3)$ \\
\hline Av. $I / a(I)$ & $12.3(4.5)$ \\
\hline \multicolumn{2}{|l|}{ Structure Refinement: } \\
\hline Resolution limits $(\AA)$ & $29.54-1.85(1.92-1.85)$ \\
\hline No. of reflections & $52628(4991)$ \\
\hline$R$ factor $(\%)$ & $19.8(37.3)$ \\
\hline$R_{\text {free }}(\%)$ & $25.3(37.8)$ \\
\hline \multicolumn{2}{|c|}{ R.m.s.d from standard geometry: } \\
\hline Bond lengths $(\AA)$ & 0.10 \\
\hline Bond angles $\left({ }^{\circ}\right)$ & 1.4 \\
\hline \multicolumn{2}{|l|}{ Dihedral angles: } \\
\hline Preferred (\%) & 95.92 \\
\hline Allowed regions $(\%)$ & 4.08 \\
\hline \multicolumn{2}{|l|}{ Average $B$ factors $(\AA)$} \\
\hline All atoms & 25.5 \\
\hline Protein & 22.5 \\
\hline Heme/NO & $20.5 / 18.6$ \\
\hline Water/Cacodylate & $35.4 / 75.4$ \\
\hline DD-1/RSR13 & 37.0 \\
\hline NO3 & 46.4 \\
\hline
\end{tabular}

